\title{
Assimilation of IASI satellite CO fields into a global chemistry transport model for validation against aircraft measurements
}

\author{
A. Klonecki ${ }^{1}$, M. Pommier ${ }^{2,}$, C. Clerbaux ${ }^{2,3}$, G. Ancellet ${ }^{2}$, J.-P. Cammas ${ }^{4}$, P.-F. Coheur ${ }^{3}$, A. Cozic ${ }^{5}$, G. S. Diskin ${ }^{6}$, \\ J. Hadji-Lazaro ${ }^{2}$, D. A. Hauglustaine ${ }^{5}$, D. Hurtmans ${ }^{3}$, B. Khattatov ${ }^{7}$, J.-F. Lamarque ${ }^{7}$, K. S. Law ${ }^{2}$, P. Nedelec ${ }^{4}$, \\ J.-D. Paris ${ }^{5}$, J. R. Podolske ${ }^{8}$, P. Prunet ${ }^{1}$, H. Schlager ${ }^{9}$, S. Szopa ${ }^{5}$, and S. Turquety ${ }^{10}$ \\ ${ }^{1}$ NOVELTIS, Ramonville-Saint-Agne, France \\ ${ }^{2}$ UPMC Univ. Paris 06; Université Versailles St-Quentin; CNRS/INSU, LATMOS-IPSL, Paris, France \\ ${ }^{3}$ Spectroscopie de l'Atmosphère, Chimie Quantique et Photophysique, Université Libre de Bruxelles (ULB), Brussels, \\ Belgium \\ ${ }^{4}$ Université de Toulouse, CNRS, UMR5560, Laboratoire d'Aérologie, Toulouse, France \\ ${ }^{5}$ LSCE/IPSL, CEA-CNRS-UVSQ, Saclay, France \\ ${ }^{6}$ NASA Langley Research Center, MS 483, Hampton, USA \\ ${ }^{7}$ National Center for Atmospheric Research, Boulder, Colorado, USA \\ ${ }^{8}$ NASA Ames Research Center, Moffett Field, California, 94035, USA \\ ${ }^{9}$ DLR, Institut für Physik der Atmosphäre, Oberpfaffenhofen, Germany \\ ${ }^{10}$ UPMC Univ. Paris 06; Ecole Polytechnique; CNRS UMR 8539, LMD-IPSL, Palaiseau, France \\ *now at: Air Quality Research Division, Science and Technology Branch, Environment Canada, Toronto, Ontario, Canada
}

Correspondence to: A. Klonecki (andrzej.klonecki@noveltis.fr)

Received: 12 October 2011 - Published in Atmos. Chem. Phys. Discuss.: 2 December 2011

Revised: 14 April 2012 - Accepted: 17 April 2012 - Published: 22 May 2012

\begin{abstract}
This work evaluates the IASI CO product against independent in-situ aircraft data from the MOZAIC program and the POLARCAT aircraft campaign. The validation is carried out by analysing the impact of assimilation of eight months of IASI CO columns retrieved for the period of May to December 2008 into the global chemistry transport model LMDz-INCA. A modelling system based on a sub-optimal Kalman filter was developed and a specific treatment that takes into account the representativeness of observations at the scale of the model grid is applied to the IASI CO columns and associated errors before their assimilation in the model. Comparisons of the assimilated $\mathrm{CO}$ profiles with in situ $\mathrm{CO}$ measurements indicate that the assimilation leads to a considerable improvement of the model simulations in the middle troposphere as compared with a control run with no assimilation. Model biases in the simulation of background values are reduced and improvement in the simulation of very high concentrations is observed. The improvement is due to the transport by the model of the information present in the IASI $\mathrm{CO}$ retrievals. Our analysis also shows the impact of assimi-
\end{abstract}

lation of $\mathrm{CO}$ on the representation of transport into the Arctic region during the POLARCAT summer campaign. A considerable increase in $\mathrm{CO}$ mixing ratios over the Asian source region was observed when assimilation was used leading to much higher values of $\mathrm{CO}$ during the cross-pole transport episode. These higher values are in good agreement with data from the POLARCAT flights that sampled this plume.

\section{Introduction}

Carbon monoxide (CO) is a good tracer of atmospheric pollution as its lifetime allows plumes to be transported over long distances. It is emitted by the incomplete combustion of fossil fuel and biomass, and is also produced by the oxidation of methane and biogenic non-methane hydrocarbons. The latter production pathway contributes about half of the background CO (Duncan et al., 2007). CO impacts the overall global oxidising capability of the troposphere. It is an important precursor of the photochemical production of ozone

Published by Copernicus Publications on behalf of the European Geosciences Union. 
in polluted air, and it is an important sink of the hydroxyl (OH) radical in low $\mathrm{NO}_{\mathrm{x}}$ environment (Logan et al., 1981).

In the last decades several air and space-borne instruments provided information on the distribution of chemical species in the troposphere, leading to an improved understanding of the chemical and transport processes as well as emissions. In particular, tropospheric $\mathrm{CO}$ columns and profiles have been obtained from polar orbiting satellites (e.g. Gloudemans et al., 2006; Luo et al., 2007; Clerbaux et al., 2008; George et al., 2009; Deeter et al., 2010; McMillan et al., 2005) and from aircraft data either routinely available (Cammas et al., 2009) or obtained during specific campaigns (e.g. McMillan et al., 2008; Paris et al., 2009; Warneke et al., 2009). Moreover, a large multi-year database with in situ CO surface measurements has been obtained from ground-station networks (e.g. Novelli et al., 2003; Zander et al., 2008). Numerous modelling studies have been confronted with the available observations leading to additional insight into the processes leading to the distribution and transport of chemical species (e.g. Klonecki et al., 2003; Shindell et al., 2008).

Data from aircraft routine and mission flights as well as data from ground stations suffer from limited spatial coverage. Only satellite missions can provide us with global coverage, however, even for the satellite-based instruments, the availability of data is limited to the periods of the overpasses of the satellites and to the periods with favourable geophysical conditions that allow carrying out the retrievals (e.g. clear sky conditions). As previous studies have shown, the joint use of satellite and aircraft data allows to better understand the pollution transport pathways (e.g. Pommier et al., 2010). Including models brings additional insight either by using direct model simulations (e.g. Sodemann et al., 2011), or by applying data assimilation (e.g. Lamarque et al., 2004).

Assimilation techniques offer a powerful tool to propagate in space and time the information provided by the satellites. The resulting product is global and continuous with spatial resolution corresponding to the resolution of the model. The problem of lack of coincident data in space and time (e.g. Pommier et al., 2010) is thus removed. In particular, the availability of vertical assimilated profiles facilitates the comparison with in situ aircraft measurements taken at various altitudes (comparing directly with satellite products requires often a vertical integration of incomplete in-situ profiles). Besides providing global concentrations, the assimilation techniques are also used to constrain surface emissions of chemical tracers as well as to optimise parameters in physical process based emission models (e.g. Elbern and Schmidt, 1999; Fortems-Cheiney et al., 2009).

Various assimilation techniques exist to assimilate chemical tracers in chemistry-transport models (CTM). In this work we use a sequential Kalman filter approach (Katthatov et al., 2000) that was previously used to assimilate MOPITT (Measurement Measurements Of Pollution In The Troposphere) and IMG (Interferometric Monitor for Greenhouse gases) satellite CO data into the MOZART (Model of Ozone and Related chemical Tracers) (Lamarque et al., 2004; Clerbaux et al., 2001) and MOCAGE (MOdèle de Chimie Atmosphérique à Grande Echelle) CTM (Pradier et al., 2006). Here, the $\mathrm{CO}$ fields derived from IASI measurements are assimilated into the LMDz-INCA CTM model (Hauglustaine et al., 2004). The resulting fields are compared with independent aircraft observations from the MOZAIC (Measurements of OZone and water vapour by AIrbus in-service airCraft) regular data and the POLARCAT (Polar Study using Aircraft, Remote Sensing, Surface Measurements and Models, of Climate, Chemistry, Aerosols, and Transport) Arctic campaigns.

The manuscript is organized as follows: Sect. 2 describes the $\mathrm{CO}$ data as retrieved from the IASI observations. Section 3 details assimilation routines that were implemented in the LMDz-INCA model. Section 4 reports on the impact of assimilation on the column $\mathrm{CO}$ while Sect. 5 focuses on the validation of the retrieved product through a comparison of the assimilated product against available aircraft data. Section 6 contains a summary.

\section{IASI CO data used for assimilation}

\subsection{IASI measurements and CO retrievals}

The IASI (Infrared Atmospheric Sounding Interferometer) instrument was launched on 19 October 2006 aboard of the polar-orbiting MetOp-A platform. IASI is a nadir-looking Fourier Transform Spectrometer (FTS) with scanning capability across track (swath width of $2200 \mathrm{~km}$ ) that ensures a near global coverage twice per 24-hour period with morning and evening measurements (the local time of the equator crossing is 9:30 AM for the ascending orbit and 9:30 PM for the descending orbit). IASI was designed to record the top of the atmosphere thermal infrared (IR) radiation emitted by the Earth-atmosphere system. From the IASI spectra (645 to $2760 \mathrm{~cm}^{-1}$, with an apodised resolution of $0.5 \mathrm{~cm}^{-1}$ ) a range of molecules can be retrieved (Clerbaux et al., 2009; Clarisse et al., 2011).

The CO retrievals used in this study were performed with the FORLI-CO (Fast Optimal Retrievals on Layers for IASI) retrieval code described in George et al. (2009) and Hurtmans et al. (2012). This operational software, based on the optimal estimation method, can process all the IASI spectra, i.e. 1.3 millions of observations per day, in near real time thanks to the use of a fast radiative transfer model on a PC cluster.

The prior information on $\mathrm{CO}$ and the associated variancecovariance matrix were constructed using a database of observations that includes aircraft profiles from the MOZAIC program (Nédélec et al., 2003), and ACE-FTS satellite observations in the upper troposphere and above (Clerbaux et al., 2008). These observations were complemented with distributions from the LMDz-INCA global model in order to build a 


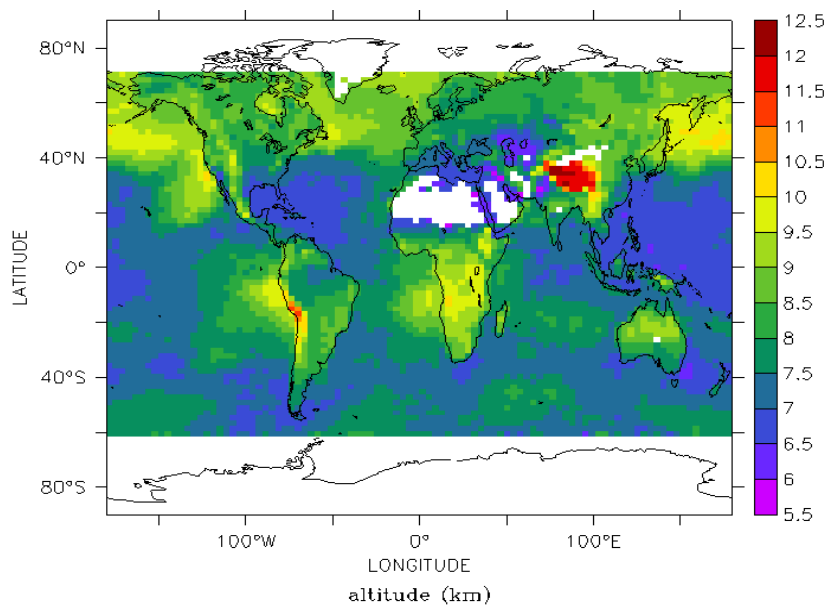

Fig. 1. Monthly mean altitude of the maximum of the IASI CO averaging kernel (in kilometres) for July 2008. The white areas indicate regions that were filtered out (see text in Sect. 2.2).

matrix representative of both background and polluted conditions (Turquety et al., 2009; Hurtmans et al., 2012).

The retrieval code provides 19 partial columns of CO defined on a vertical grid with $1 \mathrm{~km}$ resolution from the surface up to $18 \mathrm{~km}$ and the last layer corresponding to the atmosphere from 18 to $60 \mathrm{~km}$. For each retrieved profile, the retrieval method provides the estimation of the error and averaging kernel for each layer. As shown in George et al. (2009), the vertical information content is coarse and generally much lower than the number of retrieved layers. It varies between a total column and two partial columns and depends strongly on atmospheric conditions and surface type. For the thermal IR CO band used in the retrievals, the sensitivity of the measurements is generally higher for mid tropospheric layers (see Fig. 1), and the boundary layer is visible only when there is thermal contrast between the effective radiative temperature of the surface (that takes into account surface emissivity) and the temperature of the overlying air. For the morning orbit and for measurements over land, on average, the contribution from the boundary layers is higher than during evening orbit (Clerbaux et al., 2009).

\subsection{CO columns used in the assimilation}

Due to the relatively low vertical information content present in the retrieved CO products, we have chosen not to assimilate the 19 distinct layers present in the retrieval product. Instead, the total vertical CO column is assimilated along with the vertically integrated averaging kernel. This solution increases the robustness of the assimilated product and leads to considerably faster execution of the assimilation package. On the other hand, for the cases where the retrieved product contains more than one piece of information on the vertical distribution of $\mathrm{CO}$, this information is no longer contained in the vertically integrated product. For this study we accumu-

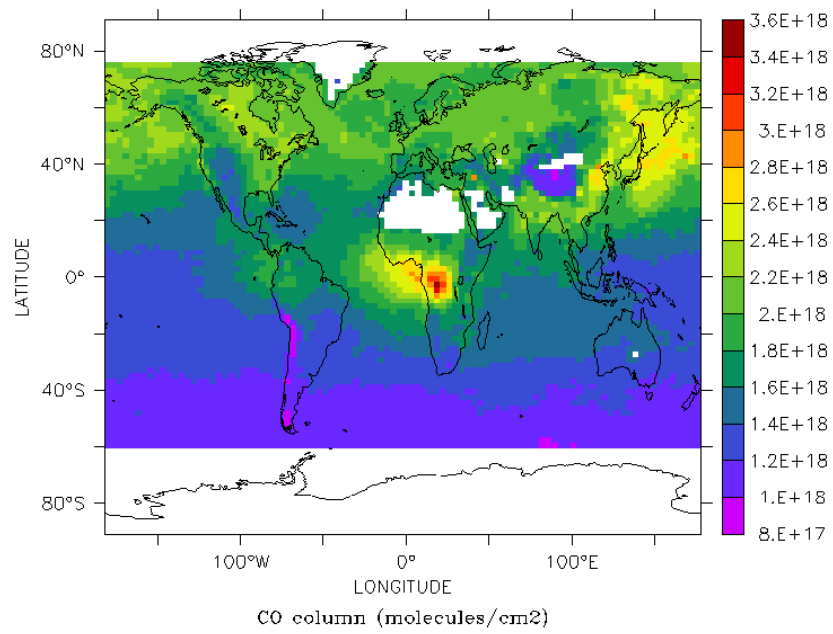

Fig. 2. Monthly mean IASI CO columns averaged over model grids for morning and evening orbit (in molecules $\mathrm{cm}^{-2}$ ) for July 2008. The white areas indicate regions that were filtered out (see text in Sect. 2.2).

lated 8 months of IASI data, from May to December 2008. Both day (local time for equator crossing - 9:30 a.m.) and night time data (local equator crossing time $-9: 30$ p.m.) are assimilated.

In order to keep only the more reliable data in the assimilation, two filters were applied: one over high latitudes and one over bright surfaces. As discussed in Pommier et al. (2010), the information content for the retrieved $\mathrm{CO}$ product is particularly low over the polar regions (DOFS of only 0.6 to 1.2 in April) due to the low surface temperatures and thus weak signal to noise ratio. The retrieved profiles over these regions show some anomalous characteristics, such as fairly strongly negative values of the averaging kernels for the levels situated near the surface. For this reason, the data to be assimilated were filtered to exclude the poles (latitudes south of $60^{\circ} \mathrm{S}$ and north of $75^{\circ} \mathrm{N}$ ).

As independent emissivity data were not available in 2008, errors in the retrieved columns were marked in certain areas, with especially unrealistically elevated columns for the morning orbits above deserts (Clerbaux et al., 2009). To filter these data, we have used a simple test based on the surface emissivity extracted from the MODIS/Terra climatology (Wan, 2008) and collocated with IASI observations. Data for regions over which this surface emissivity was below 0.94 are not used in the assimilation. Similarly, data over ice-covered regions with surface emissivity above 0.98 were not used.

Figure 2 shows the retained IASI total CO column averaged at the model resolution for July 2008. The month of July is shown as this period coincides with the POLARCAT summer campaign (see Sect. 5.2). 
a)

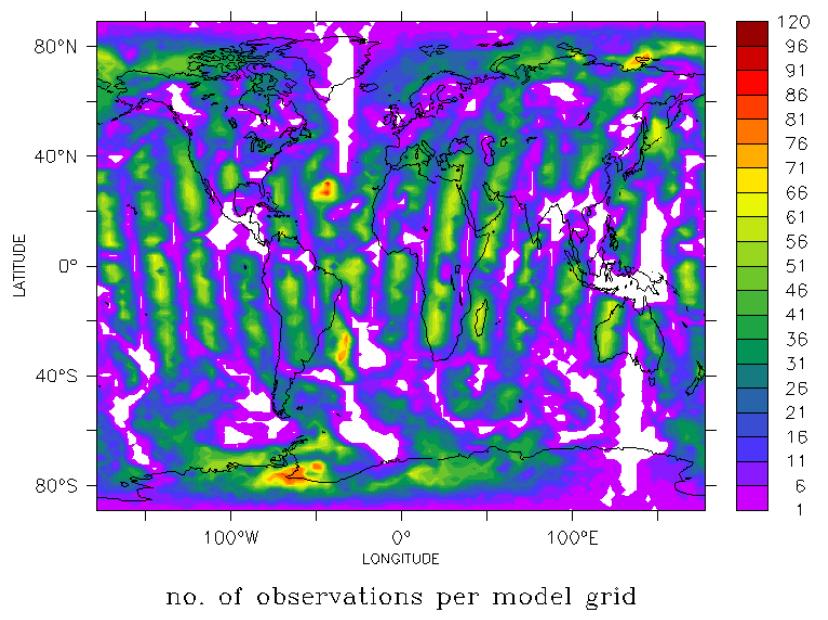

b)

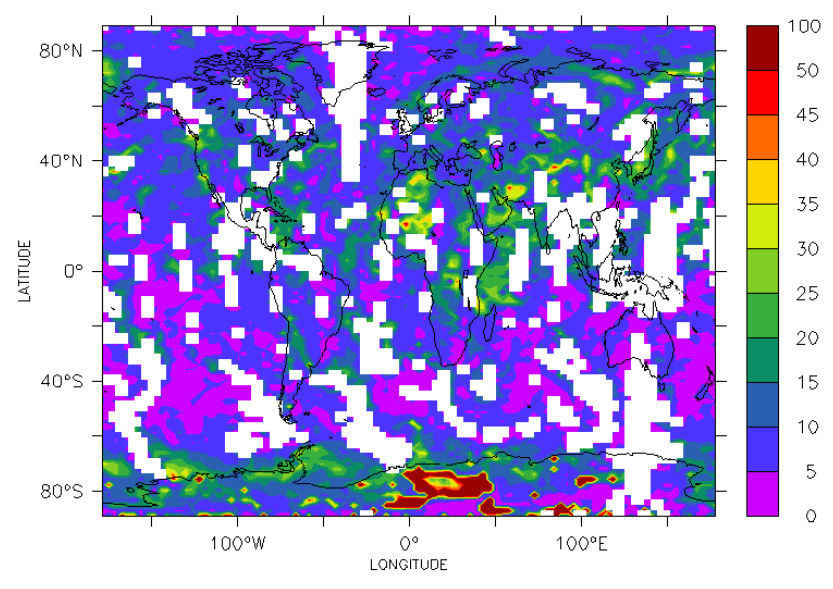

(\%)

Fig. 3. (a): Number of individual measurements of the CO column per model grid during a $12 \mathrm{~h}$ period. (b): Ratio of the value of standard deviation calculated on individual measurements of the $\mathrm{CO}$ column inside each model grid and the mean value of the $\mathrm{CO}$ column (in \%). Both figures are generated for data from 00:00 UTC until 12:00 UTC for 6 July 2008. White areas indicate model griboxes with no observations for this particular period.

\subsection{Superobservations}

The retrieved CO columns characterise $\mathrm{CO}$ content in a cone with a spatial extent corresponding to the size of one IASI pixel (about $12 \mathrm{~km}$ at nadir). As the model gridboxes are considerably larger (their size is $3.75^{\circ}$ in longitude $\times 1.89^{\circ}$ in latitude) and as there is often more than one measurement per model grid for a given assimilation window, a pre-processing of the data was necessary prior to assimilation. We have used an approach in which all the observations taken during a predefined observation window and falling into a given model gridbox are grouped into a single observation, called there- after superobservation. We have chosen the length of the assimilation window to be $30 \mathrm{~min}$. This approach is commonly used in assimilation studies in which the size of model grids exceeds the measurement footprint and several measurements are available for sampled model grid (e.g. Lamarque et al., 1999; Clerbaux et al., 2001). Figure 3a shows the number of retrieved $\mathrm{CO}$ observations over a 12 -h period that fall into each model grid.

Even though the approach of superobservations is commonly used, the implementation can depend on the case studied. In this work, due to the frequent presence of high intragrid spatial CO gradients, the question of representativeness of observations is addressed. Sharp horizontal gradients in the retrieved CO IASI columns exist due to the presence of, for example, pronounced $\mathrm{CO}$ plumes from forest fires. When both elevated and background CO columns fall in the same model grid, the total error on the superobservation should reflect not only the individual observation errors but also the high variability. Figure $3 \mathrm{~b}$ shows the variability calculated on all of the individual observations for 6 July 2008 that fall within model grids. The variability can be high and can exceed $30 \%$ of the mean total column. Figure $3 \mathrm{~b}$ illustrates also the retrieval problems in the Antarctic and certain desert regions (especially the Sahara) where high spatial variability in the CO column is due to the high variability in emissivity (as mentioned in Sect. 2.2 these data are not assimilated).

One way to define a superobservation is to calculate a mean, weighted by the errors on the individual measurements:

$y_{\text {superobservation }}=\frac{\sum_{i=1}^{N_{\mathrm{obs}}} y_{i} \cdot\left(1-\frac{e_{i}}{y_{i}}\right)^{2}}{\sum_{i=1}^{N_{\mathrm{obs}}}\left(1-\frac{e_{i}}{y_{i}}\right)^{2}}$

where $y_{i}$ is the individual retrieved column of $\mathrm{CO}$ and $e_{i}$ is the associated error. $N_{\text {obs }}$ is the number of observations used to generate a superobservation. Equation (1) reduces to a simple arithmetic mean if the ratio of $e_{i} / y_{i}$ is the same for all the measurements that fall into a given grid of the model.

In a similar way, the error on the superobservation can be calculated with Eq. (2). This definition corresponds to an average error calculated by taking into account the weights of individual measurements.

$e_{\text {superobservation }}=y_{\text {superobservation }} \cdot\left(1-\sqrt{\frac{\sum_{i=1}^{N_{\mathrm{obs}}}\left(1-\frac{e_{i}}{y_{i}}\right)^{2}}{N_{\mathrm{obs}}}}\right)$

If $e_{i} / y_{i}$ is the same for all measurements, Eq. (2) reduces to $y_{\text {mean }} \cdot\left(e_{i} / y_{i}\right)$.

The above definitions of superobservation and its error have several limitations: 
1. Equation (2) does not take into account the error due to the representativity of the superobservation and the information on the variability of the observations falling into a given model grid is not taken into account. One can thus have a case, when two sets of observations, one with low and one with high variability will have similar errors on the superobservations if the above formula is used. Since it is desirable to give higher error estimation for the latter case, a different formulation is needed to take into account the representativity of the superobservation. The superobservation with low variability can generally be considered as being more representative of the area covered by model grid.

2. With Eq. (2), a superobservation composed of a large number of observations can have an error that is similar to a superobservation composed of only one observation. Clearly having more observations distributed throughout the grid increases the representativity of the superobservation on the scale of the model grid. In addition, in regions with little variability, having several measurements can reduce the overall error of the mean. The exact reduction will depend on the contribution of the systematic and random errors in the individual retrievals.

3. Finally, the above definition can lead in certain regions to a strong inconsistency between the variability of the superobservations (both spatial and temporal variability) and the error on these values. The errors on superobservations obtained with Eq. (2) are of the same order as the errors on the individual retrieved columns. However, in certain regions of the globe far from emission sources, like most of the southern hemisphere, due to averaging of a relatively high number of observations, the variability (spatial and temporal) of the superobservations is very weak. We thus have a case where the differences between neighbouring superobservations (both in space: nearby grids, and in time: superobservations over a few days) are much smaller than the estimated error. Clearly the above definition does not lead to a gaussian distribution of superobservations with the specified error.

In order to address the above issues, a new definition of the error on the superobservation is proposed in this work:

$\tilde{e}_{\text {superobservation }}=\sqrt{\frac{e_{\text {superobservation }}^{2}}{N_{\text {obs }}}+V}$

where $e_{\text {superobservation }}$ is the value of the error calculated with Eq. 2 and $V$ is the variance of individual observations in a grid of the model for a given assimilation window. The first term on the right hand side accounts for the reduction of the error if more than one measurement is present in a given grid box during the predefined assimilation window while the second term accounts for the variance. In this definition, for $\mathrm{N}_{\mathrm{Obs}}$ that is sufficiently high, the second term dominates. As generally there is a high number of measurements in each grid, we use the variance of these measurements, instead of the error on the individual measurements, to estimate the effective error of the superobservation.

To have superobservations that are coherent with this definition of the error, we define them as:

$\tilde{y}_{\text {superobservation }}=y_{\text {superobservation }}+\sqrt{V} \cdot$ Rand

where $y_{\text {superobservation }}$ is calculated with Eq. (1) and Rand is a random number generator with standard deviation of one and mean of zero (Gaussian distribution). In regions with little spatio-temporal variability in the retrieved values, the second term allows having the same variability on the superobservations as was the case for individual observations $(V)$. In order not introduce too much variability on the superobservations in regions with high variability on individual measurements (such as regions close to $\mathrm{CO}$ sources), the value of $V$ in Eq. (4) is limited to $\left(2.5 \times 10^{17} \text { molec } \mathrm{cm}^{-2}\right)^{2}$. This value was chosen as it separates well the low and high variability regions (figure not shown). In the implementation proposed, the superobservations are calculated only if $N_{\mathrm{Obs}}$ is greater or equal to 4 .

The averaging kernel for each superobservation is calculated using a standard averaging formalism. For a vertical level $k$, the definition given in Eq. (5) was applied to average all $N_{\text {Obs }}$ averaging kernels for each grid of the model.

$A(k)=\frac{\sum_{i=1}^{N_{\text {obs }}} A(k, i) \cdot\left(1-\frac{e_{i}}{y_{i}}\right)^{2}}{\sum_{i=1}^{N_{\text {obs }}}\left(1-\frac{e_{i}}{y_{i}}\right)^{2}}$

$A(k)$ is the value of the obtained averaging kernel at level $k$, $A(k, i)$ are the values at level $k$ for each individual profile $i$.

\section{Assimilation methodology}

\subsection{The LMDz-INCA model}

In this work we have used the Laboratoire de Météorologie Dynamique (LMDz) General Circulation Model (Hourdin et al., 2006) coupled with the INteraction with Chemistry and Aerosols (INCA) model (Hauglustaine et al., 2004; Folberth et al., 2006). The chemical scheme used in this study takes into account the $\mathrm{CH}_{4}-\mathrm{NO}_{\mathrm{x}}-\mathrm{CO}-\mathrm{O}_{3}$ chemistry of the background troposphere as well as a detailed non-methane hydrocarbon scheme. We ran the model with a resolution of 96 grid points in longitude and 95 in latitudes $\left(3.75^{\circ}\right.$ in longitude $\times 1.89^{\circ}$ in latitude) and 19 vertical levels. The model uses $\sigma$-p vertical coordinates with 19 levels extending from the surface up to about $3 \mathrm{hPa}$. The vertical resolution is of about $300-500 \mathrm{~m}$ in the planetary boundary layer (first level 
at $70 \mathrm{~m}$ ) and between 1 and $2 \mathrm{~km}$ in the remaining parts of the troposphere. The model has been run in a nudged mode with winds relaxed towards ECMWF reanalysis. The relaxation of the GCM winds towards ECMWF meteorology is performed by applying a correction term to the calculated GCM wind horizontal components $(u, v)$ corresponding to a relaxation time of $2.5 \mathrm{~h}$ over the whole model domain. The ECMWF fields are provided every $6 \mathrm{~h}$ and interpolated onto the LMDz grid. For the results reported here we use the winds for year 2008 corresponding to the period of interest for the POLARCAT campaign.

We have used the inventories for anthropogenic emissions prepared for the Climate Model Intercomparison Project \#5 (CMIP5) in support of the Intergovernmental Panel on Climate Change (IPCC) Fifth Assessment report (AR5) by Lamarque et al. (2010). These inventories provide emissions of chemical precursors for climate simulations in order to study the long-term change of the atmospheric chemical composition. In this study we use the emissions corresponding to the year 2000. Grassland burning and forest fire emissions are prescribed according to the GFEDv2 (Global Fire Emissions Database version 2) inventories (van der Werf et al., 2006). GFEDv2 provides a range of information including burned area, fuel load, combustion completeness and emissions from fires for a series of gases and aerosols at $1^{\circ} \times 1^{\circ}$ spatial resolution. The fluxes used represent a mean for the 1997-2004 period. Van der Werf et al. (2006) states that this inventory represents well the fire seasonality in boreal ecosystems and global wetland due to the improved modelling of fuel loads. Biogenic emissions from Lathière et al. (2006) are used for isoprene and monoterpenes as well as for emissions of other reactive chemical species such as methanol, acetone, aldehydes, and organic acids.

\subsection{Kalman filter}

The assimilation scheme used here belongs to the class of the optimal estimation methods in which a solution that minimizes a cost function is found. The cost function contains two terms that depend on the difference between the model and the observations and on the difference between the model and the background knowledge. Both terms are weighted by the covariance error matrices that express our confidence levels in the observations and in background model information. The assimilation approach used in this paper is based on the sub-optimal Kalman filter described in Khattatov et al. (2000). In this sequential assimilation approach, for each assimilation window of $30 \mathrm{~min}$, a new analysis is calculated using the following equation:

$x_{a}=x_{b}+\mathbf{K}\left(y-H\left(x_{b}\right)\right)$

where $x_{a}$ and $x_{b}$ are the model analysis and forecast respectively. Both $x_{a}$ and $x_{b}$ are defined on the model vertical levels (in the units of volume mixing ratios) and are provided for model grids for which information is provided by the ob- servations. $\mathbf{K}$ is the Kalman gain matrix and $H$ is the observational operator that allows transforming the information from the model space ( $\mathrm{CO}$ profiles on a model horizontal and vertical grids) to the observation space allowing a comparison of model CO profiles $\left(\mathrm{x}_{b}\right)$ and superobservation for total $\mathrm{CO}$ columns retrieved from IASI data. The retrieved column in the optimal estimation algorithm contains a contribution both from the real profile and from the a priori used in the retrieval:

$y=\boldsymbol{A}^{*} x_{\mathrm{r}}+\left(d p^{\mathrm{T}}-\boldsymbol{A}\right) \cdot x_{\mathrm{ap}}$

where $x_{\mathrm{r}}$ is the real profile (unknown), $x_{\mathrm{ap}}$ is the a priori profile used in the inversion of the IASI radiances, and $d p^{\mathrm{T}}$ is the transpose of the vector containing the pressure thicknesses of the 19 vertical layers. The product of $d p^{T}$ and $x_{\text {ap }}$ gives the a priori total CO column. $\boldsymbol{A}$ is the normalised averaging kernel vector defined on 19 levels. It characterises the contribution of these layers to the total retrieved column. Similar equation in which $x_{\mathrm{r}}$ is replaced by $x_{b}$ is used to construct the corresponding model value $\left(H\left(x_{b}\right)\right.$ in Eq. (6)).

$\mathbf{K}$ in Eq. (6) is calculated as follows:

$\mathbf{K}=\mathbf{B} H^{\mathrm{T}}\left(H \mathbf{B} H^{\mathrm{T}}+\mathbf{O}+\mathbf{R}\right)^{-1}$

where $\mathbf{B}$ is the model variance-covariance error matrix, $\mathbf{O}$ is the observation variance-covariance error matrix, and $\mathbf{R}$ is the representativity error of the superobservation (term $\sqrt{V}$. Rand in Eq. (4)).

The method of the Kalman filter allows calculating the impact of assimilation on the error of the model (the model improves as a result of assimilation):

$\mathbf{B}^{\mathrm{a}}=(I-\mathbf{K} H) \mathbf{B}$

where $\mathbf{B}^{\mathrm{a}}$ is the variance-covariance matrix of the model error after assimilation.

\subsection{Model error}

Besides characterizing the error on the observations, it is also necessary to provide an estimation of the model's variancecovariance error matrix. Relative values of model and observational error will determine the impact of observations on the model's CO column. The vertical correlation and vertical distribution of the model's error will also have an impact on deciding which vertical levels of the model will be impacted by the assimilation of the $\mathrm{CO}$ columns.

The parameterisation of the model's variance-covariance matrix (B matrix) follows Khattatov et al. (2000). Given the size of the $\mathbf{B}$ matrix, several simplifications are necessary: the cross-correlation terms in the matrix are based on correlation lengths and are calculated as needed using the parameterisations specified in Table 1. Equation (9) is applied only to calculate the diagonal terms. The initial model error in each model grid $(f)$ was set to $50 \%$ of the CO concentrations at the beginning of the simulation. Several simulations were 
Table 1. List of adjustable parameters that define the variance-covariance error matrix $\mathbf{B}$. CO is the mixing ratio of $\mathrm{CO}$ in (ppbv), $p_{i}$ and $p_{j}$ are the pressures (in Pa) of two vertical model levels, Dist $(i, j)$ is the horizontal distance between centers of model gridboxes $i$ and $j, b_{i, j}$ is the calculated term of the model error covariance matrix.

\begin{tabular}{llll}
\hline Variable & Symbol & Implementation & Value used \\
\hline Initial Error & $f$ & $\mathbf{B}=\left(f^{*} \mathrm{CO}\right)^{2}$ for diagonal terms & 0.5 (no units) \\
Error growth term & $\varepsilon$ & $\mathbf{B}^{\mathrm{a}}=\mathbf{B}+\left(\varepsilon^{*} \mathrm{CO}\right)^{2}$ for diagonal terms & 0.01 (no units) \\
Vertical correlation length & $\mathrm{L}_{z}$ & $b_{i, j}=\sqrt{b_{i, i} b_{j, j}} \exp \left(-\left(\frac{\left(\ln \left(p_{i}\right)-\ln \left(p_{j}\right)\right)}{L_{z}}\right)^{2}\right)$ & 0.4 (scale height) \\
Horizontal correlation length & $\mathrm{L}_{x y}$ & $b_{i, j}=\sqrt{b_{i, i} b_{j, j}} \exp \left(-\left(\frac{\operatorname{Dist}(i, j)}{L_{x y}}\right)^{2}\right)$ & $500(\mathrm{~km})$ \\
\hline
\end{tabular}

carried out to select optimal values for the remaining adjustable parameters: error growth term $(\varepsilon)$, as well as the vertical $\left(\mathrm{L}_{\mathrm{z}}\right)$ and horizontal correlation lengths $\left(\mathrm{L}_{\mathrm{xy}}\right)$. As specified in Khattatov et al. (2000) the $\chi^{2}$ (chi2) test and the OmF (Observations minus Forecast) values were used to select final values: the error growth term was set in this study to 0.01, and the vertical $\left(\mathrm{L}_{z}\right)$ and horizontal $\left(\mathrm{L}_{\mathrm{xy}}\right)$ correlation lengths were fixed at $0.4^{*}$ atmospheric scale height (atmospheric scale height $\sim 7 \mathrm{~km}$ ) and $500 \mathrm{~km}$ respectively.

\subsection{Chi2 test}

In order to test the coherence of the parameterisation of the model error (Sect. 3.3) and of the superobservations (Section 2.3), we apply the chi2 test. The chi2 test allows testing the coherence of the assimilation by comparing the difference between the model and observations $(\mathrm{OmF}=\mathrm{y}-\mathrm{H}(\mathrm{x}))$ and the specified model and observational errors. The diagnostic variable chi2 is defined as follows:

$\operatorname{chi} 2=\left(y-H\left(x_{b}\right)\right)^{\mathrm{T}} \cdot\left(H \mathbf{B} H^{\mathrm{T}}+\mathbf{O}+\mathbf{R}\right)^{-1} \cdot\left(y-H x_{b}\right)$

For a fully coherent simulation, the mean value of the chi2 diagnostic should fall close to 1 . Having values different than 1 indicates that either the model and/or observational errors are too high (chi2 smaller than 1) or too low (chi2 greater than 1) as compared with $\mathrm{OmF}$.

With the definition of superobservations used in this work (Eq. 3 and Eq. 4), it is possible, by selecting parameters for the model error, to obtain chi2 close to 1 . The chi 2 values obtained for the chosen set of parameters are shown in Fig. 4 for July 2008. In this figure, chi2 was averaged for each assimilation window over all grids containing superobservations. Even though for certain assimilation windows the value of chi 2 can be far from 1 , the mean value is very close to the desired result. In addition, there is no trend in the chi2 values, indicating that the parameterisation (especially model error growth term $\varepsilon$ ) leads to stable values of model error.

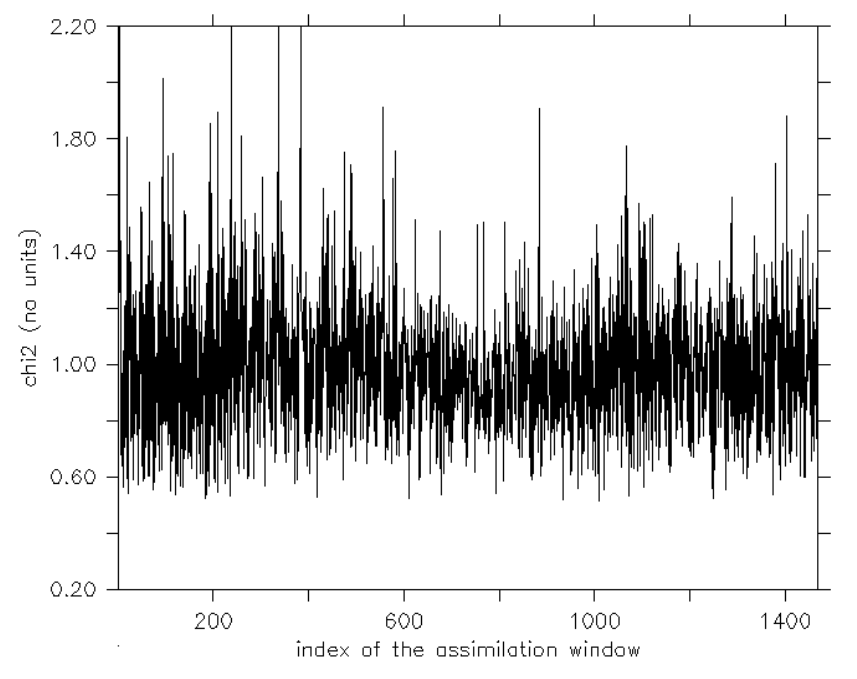

Fig. 4. Chi2 parameter averaged for all model grids for each of the $30 \mathrm{~min}$ assimilation windows. Chi2 is plotted as a function of the number of assimilation windows available for July 2008.

\section{Impact of assimilation on the simulated total CO columns}

In this section we evaluate the impact of the assimilation by comparing the IASI CO products with the columns simulated with and without assimilation. Note than the model run time is doubled when IASI data are assimilated. Figure 5 shows the CO total columns simulated by the model with assimilation (Fig. 5a) and for the control run in which observations were not assimilated (Fig. 5b). Figure 5c shows the impact of assimilation with the difference between the assimilation and control runs. The averaged fields for July 2008 are plotted. Over the Northern Hemisphere assimilation leads to a consistent increase in the column CO. The strongest increase is over the North Pacific and the Canadian Arctic where the difference reaches $6 \times 10^{17}$ molecules $\mathrm{cm}^{-2}$. Lower $\mathrm{CO}$ columns in the control run indicate a likely underestimation of $\mathrm{CO}$ sources from eastern Asia and possibly also from boreal forest fires over North America. Assimilation increases also the CO column over the north Atlantic and most of Eurasia. There are also two regions in 
Table 2. Quantification of the impact of assimilating observations (IASI CO columns) on the difference between the observations $\left(\mathrm{O}_{i}\right)$ and the simulated model CO columns. The results are shown for both model results with assimilation $\mathrm{M}_{A, i}$, and the control run ( $\left.\mathrm{M}_{C, i}\right)$. The impact is calculated separately for the 8 months of simulations.

\begin{tabular}{llllll}
\hline Month & $\begin{array}{l}\text { Mean absolute } \\
\text { difference: } \\
\text { abs }\left(\mathrm{O}_{i}-M_{A, i}\right)\end{array}$ & $\begin{array}{l}\text { Mean absolute } \\
\text { difference: } \\
\mathrm{abs}\left(\mathrm{O}_{i}-M_{C, i}\right)\end{array}$ & $\begin{array}{l}\text { Mean relative } \\
\text { difference: } \\
\left(\frac{\mathrm{abs}\left(\mathrm{O}_{i}-M_{A, i}\right)}{\mathrm{O}_{i}}\right)\end{array}$ & $\begin{array}{l}\text { Mean relative } \\
\text { difference: } \\
\left(\frac{\mathrm{abs}\left(\mathrm{O}_{i}-M_{C, i}\right)}{\mathrm{O}_{i}}\right)\end{array}$ & $\begin{array}{l}\text { Number of } \\
\text { superobservations }\end{array}$ \\
\hline May & $1.07 \times 10^{17}$ & $3.09 \times 10^{17}$ & 0.055 & 0.149 & 315880 \\
June & $1.02 \times 10^{17}$ & $2.87 \times 10^{17}$ & 0.056 & 0.153 & 331458 \\
July & $1.26 \times 10^{17}$ & $3.18 \times 10^{17}$ & 0.070 & 0.171 & 378687 \\
August & $1.15 \times 10^{17}$ & $2.44 \times 10^{17}$ & 0.068 & 0.148 & 271233 \\
September & $1.27 \times 10^{17}$ & $2.35 \times 10^{17}$ & 0.075 & 0.145 & 370937 \\
October & $1.26 \times 10^{17}$ & $2.34 \times 10^{17}$ & 0.076 & 0.146 & 365695 \\
November & $1.23 \times 10^{17}$ & $2.17 \times 10^{17}$ & 0.076 & 0.142 & 367931 \\
December & $1.24 \times 10^{17}$ & $2.17 \times 10^{17}$ & 0.081 & 0.152 & 266276 \\
\hline
\end{tabular}

a)
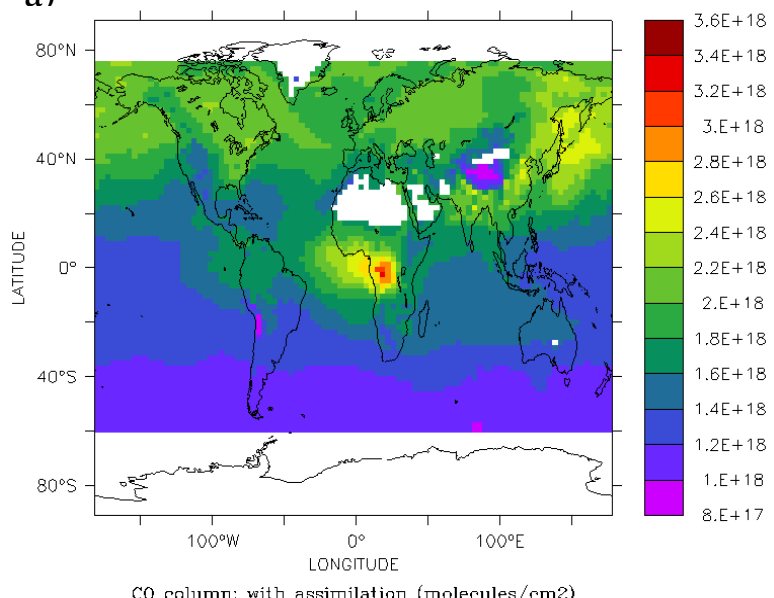

c)

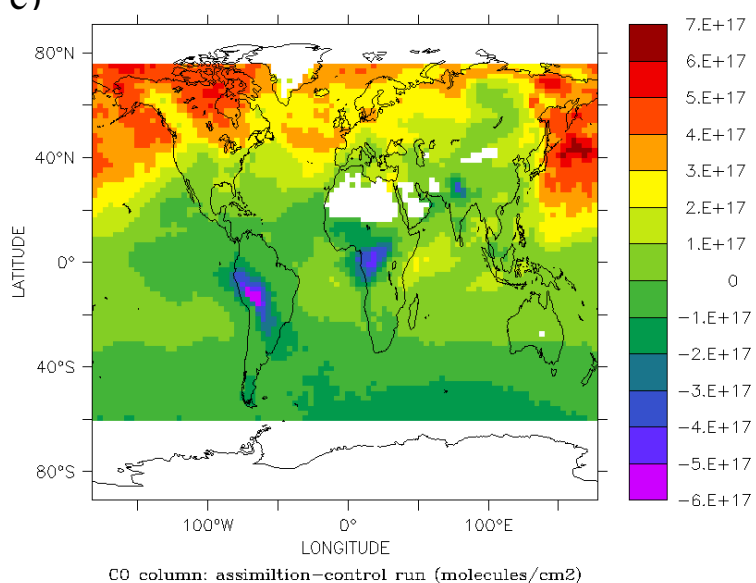

b)

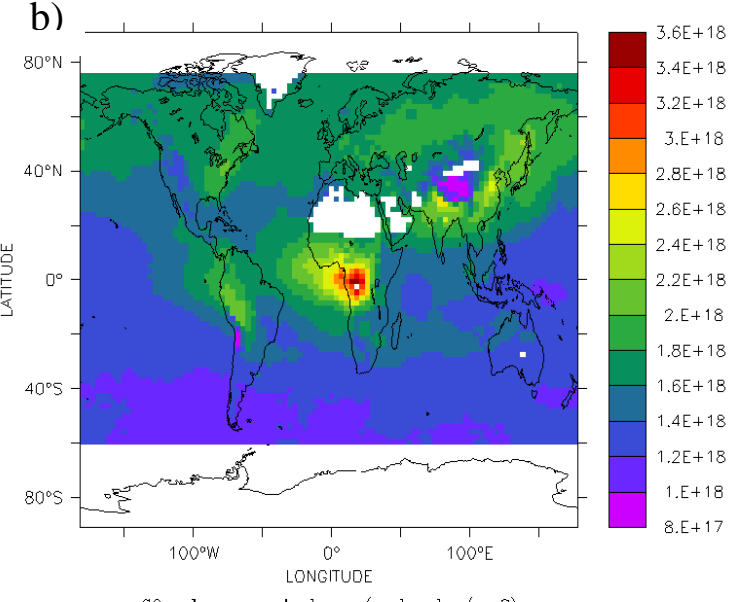

Co column: control run (molecules/cm2)

Fig. 5. Monthly averaged CO columns for July 2008 simulated by the model for a run with assimilation (a), model without assimilation (control run) (b) and for the difference between these two simulations (impact of assimilation = simulation with assimilation-control)) $(\mathbf{c})$. The CO columns are calculated by applying the averaging kernels supplied with each observation to the model analysis. 

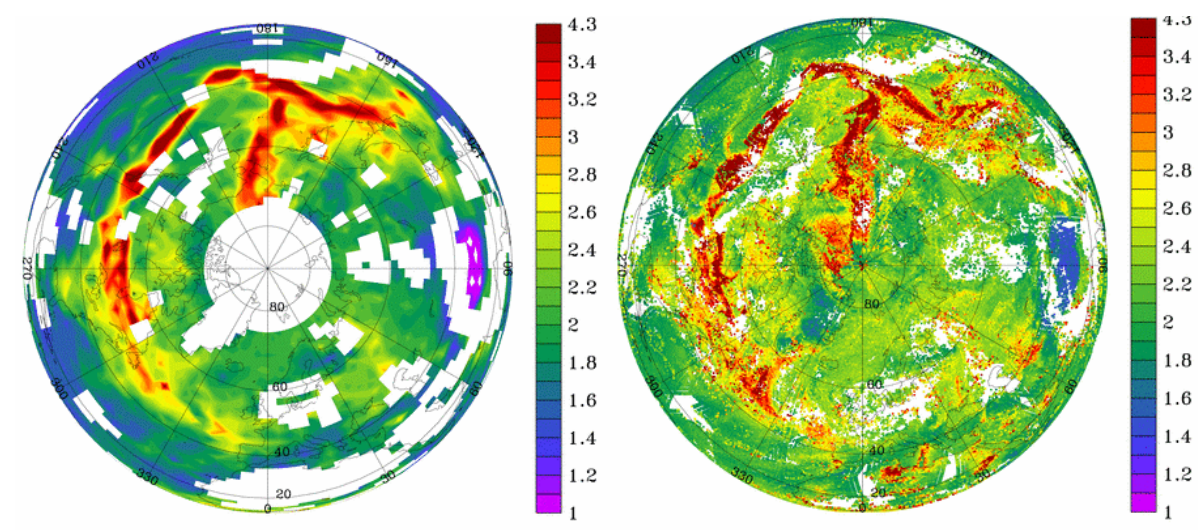

CO column(mol/cm2*1E18),IASI superobs.

CO column(mol/cm2*1E18), IASI L2

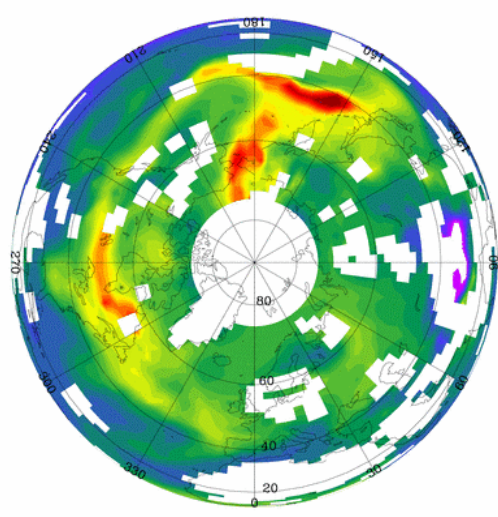

CO column $\left(\mathrm{mol} / \mathrm{cm}^{2}{ }^{*} 1 \mathrm{E} 18\right)$, assimilation run

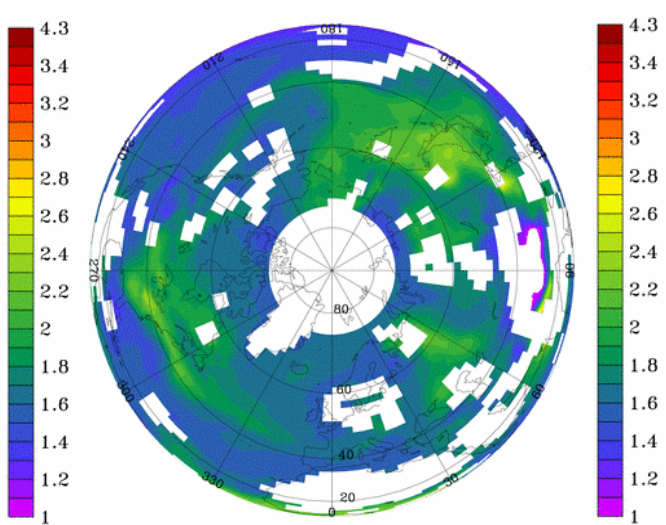

$\mathrm{CO}$ column(mol/cm2*1E18), control run

Fig. 6. Maps for 7 July 2008 for IASI CO superobservations (upper left), IASI CO individual observations (upper right), model with assimilation (lower left), control run (lower right). For individual observations all available data are plotted (both day and night which leads to overlap) while for the remaining panels the mean values are plotted. The white areas indicate model grid boxes with less than four IASI CO measurements retained during this 24 -h period or regions that were filtered.

the tropics: the eastern equatorial Africa and tropical South America where assimilation leads to a consistent decrease in the $\mathrm{CO}$ columns. The results shown in Fig. 5 are for column values; the implications for different levels of the profiles will be discussed in Sect. 5.3.

Figure 6 shows the observations (both the individual observations and the superobservations) as well as model results from the runs with and without assimilation for 7 July 2008 - a day with a strong cross-pole transport event. The comparison of the two figures showing observations indicates that the superobservations capture well the patterns and range of values seen in the individual observations. The strong CO plumes are generally well reproduced in the assimilation run, even though the highest values in the centres of the plumes are underestimated with respect to observations. The difference with respect to observations is considerably stronger for the control run. For example, the fire plume that is visible in the IASI data and which corresponds to the strong transport event into the high Arctic (Pommier et al.,
2010), is better represented in the run with assimilation than in the control run. This transport episode is addressed further in comparisons with in situ data in Sect. 5.3.

The mean positive impact of assimilation on the comparison with the IASI CO columns is quantified for all months of the simulation in the Table 2. These results indicate that assimilation leads to a considerable reduction of the mean absolute difference between the model simulated values and the observations. The mean relative absolute difference between the observations $(\mathrm{O})$ and the model $(\mathrm{M})$ $\left(1 / N \sum_{i=1}^{N} \frac{\mathrm{abs}\left(\mathrm{O}_{i}-\mathrm{M}_{i}\right)}{\mathrm{O}_{i}}\right)$ is reduced from about $14-17 \%$ error for the control run to about 5-8\% error for the run with assimilation ( $N$ in the equation is the number of superobservations in each month, and $i$ is the index of the superobservations and corresponding model value). 
CO (ppbv): observations MOZAIC 250mb till 200mb may
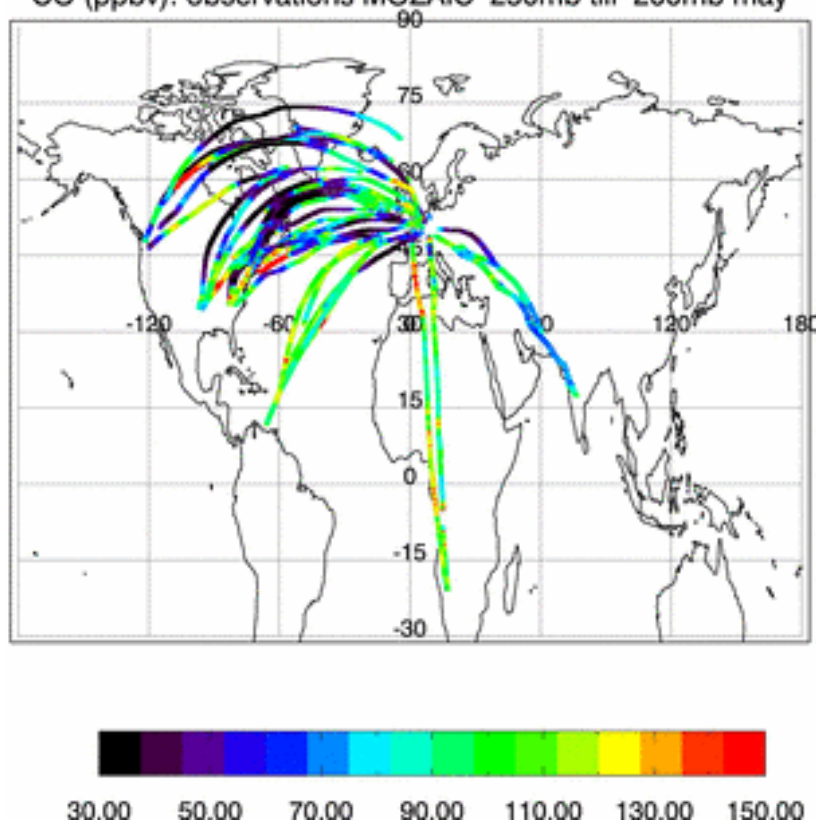

Fig. 7. $\mathrm{CO}$ observations (in ppbv) from MOZAIC measurements taken in May 2008 between 200 and $250 \mathrm{mb}$.

\section{Validation of the IASI CO product by comparing against independent data from aircraft campaigns}

The IASI derived CO data have been analysed in detail and validated using other satellite data (George et al., 2009), but as detailed in Pommier et al. (2010) direct validation of level 2 products using aircraft observation remains difficult. Assimilation can be seen as a tool that facilitates this task by removing the constraint of having both types of observations collocated in space and time. In addition, assimilated products allow comparison at the vertical levels at which the in situ data are available. To compare directly with satellite data, even if a vertical profile is retrieved, application of the averaging kernels to smooth the in situ profiles is necessary to have a meaningful comparison (Pommier et al., 2010). On the other hand, the assimilated products contain the contribution from the model that can be important in certain cases.

\subsection{MOZAIC data}

We first compare the model results with $\mathrm{CO}$ measurements obtained by the MOZAIC aircraft measurement program (Nédélec et al., 2003). Because these measurements were obtained by commercial aircraft, their geographical positions are limited to the usual flight corridors (Fig. 7) with most of the measurements available at the flight altitude of about $12 \mathrm{~km}$. The atmospheric profiles are available only near the airports. Despite these limitations, and thanks to the high number of measurements, these data remain an exceptional dataset for validating model results.
Due to the large number of flights, the average of the MOZAIC data represents well climatological conditions, however, the data contain also numerous outliers corresponding to aircraft flying through $\mathrm{CO}$ anomalies. Figure 7 shows that the $\mathrm{CO}$ values for May 2008 at the cruising altitude are highly non-uniform. Several air masses with high $\mathrm{CO}$ were sampled mostly over the North American continent. To compare the $\mathrm{CO}$ assimilated fields with aircraft observations, we sampled the model at the time and location of the measurements. The sampling was done by performing temporal and spatial interpolation of the model results onto the positions of the measurements. This sampling was done during the execution of the chemistry transport model in order to benefit from the original temporal resolution of the model, which corresponds to model's physical time step. The comparison of the measured and modelled $\mathrm{CO}$ values averaged over three latitude bands and $50 \mathrm{mb}$ pressure bins is shown for the month of May in Fig. 8. In order to evaluate the impact of assimilation, the results are shown for both the control and assimilation runs. The panels on the left side of the figure show that in the mid-troposphere the means and medians obtained with assimilation are considerably closer to the measured values for all latitude bands for which the MOZAIC measurements are available. In the mid-troposphere of the northern hemisphere ( 30 to $45^{\circ} \mathrm{N}$ and 45 to $60^{\circ} \mathrm{N}$ ) the original mean bias of about 10 to $30 \mathrm{ppbv}$ present in the control simulation is considerably reduced when $\mathrm{CO}$ data are assimilated. The mean absolute differences in $\mathrm{CO}$ mixing ratios (centre panels of the figure) are reduced to about 10-15 ppbv from the original difference that is generally 5 to 20 ppbv higher. Near the surface, the positive impact of assimilation is less obvious, especially in the $30-45^{\circ} \mathrm{N}$ latitude band, where assimilation seems to increase the mean bias. As discussed before, the values near the surface are not well constrained by the total column. In the tropics, the original model bias in the mid-troposphere is smaller, and assimilation helps to reduce it even further. For measurements situated near or above the tropopause, due to the relatively long vertical correlation lengths that are independent of the pressure level (Sect. 3.3) and limited vertical resolution of the model, assimilation can lead to a slight degradation of the results as shown for example for the 45$60^{\circ} \mathrm{N}$ latitude band.

In Fig. 9 we show the results for the 8 months and only for the $45^{\circ} \mathrm{N}-60^{\circ} \mathrm{N}$ latitude band which contains the highest number of measurements. With the exception of the surface values, this figure shows that assimilation helps improving the seasonal cycle of $\mathrm{CO}$. The impact of assimilation is seen especially for the first three months of the simulation, for which the control run has on average too low CO mixing ratios, and near the end of the simulation, where these values are too high. Near the surface, the improvement is less obvious. Similar improvements are also observed for other latitude bands: $30^{\circ} \mathrm{S}-30^{\circ} \mathrm{N}$ and $30^{\circ} \mathrm{N}-45^{\circ} \mathrm{N}$ (figures not shown). 

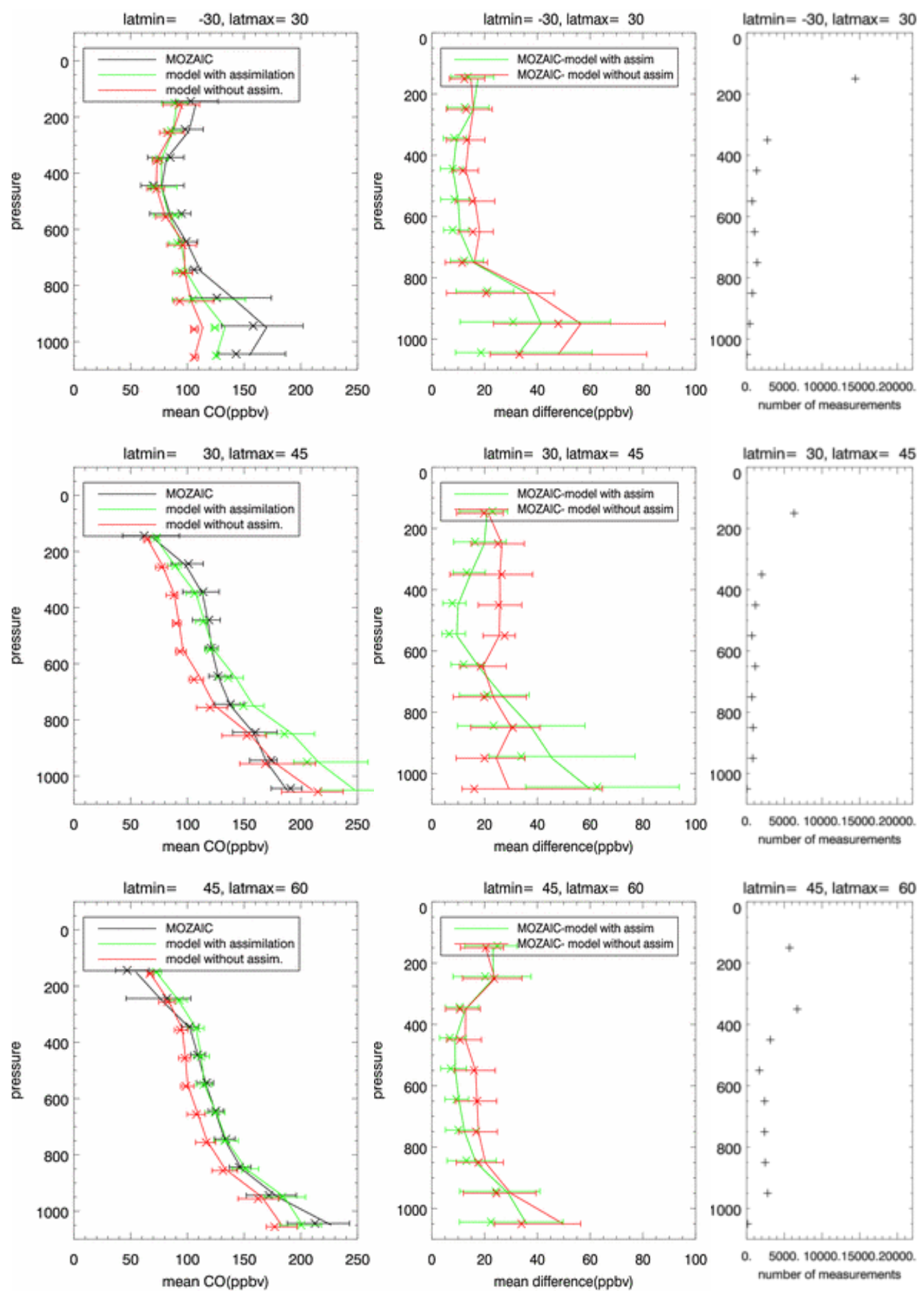

Fig. 8. Left column: solid lines indicate monthly averaged CO for: MOZAIC (black curve), LMDz-INCA with assimilation of IASI CO products (green curve) and LMDz-INCA control run (red curve). Centre column: mean absolute differences between: MOZAIC data and assimilation run (green curve) and MOZAIC and control run (red curve). The horizontal bars in the left and centre column panels indicate the 25 and 75 percentiles, and the symbol $\mathrm{x}$ indicates the median. The right column indicates the number of MOZAIC measurements. The number of measurements in the $200-300 \mathrm{mb}$ bin is off the scale of the figure. The results are shown for May 2008, for data in three latitude bands: $30^{\circ} \mathrm{S}-30^{\circ} \mathrm{N}$ (top figures), $30^{\circ} \mathrm{N}-45^{\circ} \mathrm{N}$ (centre figures), and $45^{\circ} \mathrm{N}-60^{\circ} \mathrm{N}$ (bottom figures) and $100 \mathrm{hPa}$ pressure bins. 
Table 3. Number of measurements $(N)$ and correlation coefficients $(R)$ between MOZAIC CO data and model results obtained with assimilating IASI CO data and without assimilation (control). The results are shown for data for 4 pressure bins: pressures higher than $800 \mathrm{mb}$, between 800 and $600 \mathrm{mb}$, between 600 and $400 \mathrm{mb}$, and between 400 and $300 \mathrm{mb}$.

\begin{tabular}{|c|c|c|c|c|c|c|c|c|c|c|c|c|}
\hline \multirow[t]{2}{*}{ Month } & \multicolumn{3}{|c|}{$\mathrm{P}>800 \mathrm{mb}$} & \multicolumn{3}{|c|}{$800 \mathrm{mb}>P>600 \mathrm{mb}$} & \multicolumn{3}{|c|}{$600 \mathrm{mb}>P>400 \mathrm{mb}$} & \multicolumn{3}{|c|}{$400 \mathrm{mb}>P>300 \mathrm{mb}$} \\
\hline & $N$ & $\begin{array}{l}R \\
\text { With }\end{array}$ & $\begin{array}{l}R \\
\text { Control }\end{array}$ & $N$ & $\begin{array}{l}R \\
\text { With }\end{array}$ & $\begin{array}{l}R \\
\text { Control }\end{array}$ & $N$ & $\begin{array}{l}R \\
\text { With }\end{array}$ & $\begin{array}{l}R \\
\text { Control }\end{array}$ & $N$ & $\begin{array}{l}R \\
\text { With }\end{array}$ & $\begin{array}{l}R \\
\text { Control }\end{array}$ \\
\hline May & 8271 & 0.43 & 0.44 & 9068 & 0.66 & 0.53 & 8826 & 0.84 & 0.73 & 11474 & 0.63 & 0.46 \\
\hline June & 11865 & 0.68 & 0.65 & 13787 & 0.68 & 0.47 & 13014 & 0.78 & 0.64 & 18776 & 0.47 & 0.57 \\
\hline July & 7871 & 0.61 & 0.54 & 9665 & 0.75 & 0.63 & 9694 & 0.75 & 0.33 & 14020 & 0.56 & 0.23 \\
\hline August & 10384 & 0.67 & 0.69 & 12807 & 0.86 & 0.87 & 12364 & 0.52 & 0.39 & 19464 & 0.36 & 0.51 \\
\hline September & 11725 & 0.59 & 0.55 & 13642 & 0.89 & 0.76 & 13845 & 0.72 & 0.67 & 17943 & 0.65 & 0.55 \\
\hline October & 10840 & 0.52 & 0.51 & 14686 & 0.81 & 0.56 & 12388 & 0.85 & 0.76 & 17375 & 0.56 & 0.46 \\
\hline November & 15838 & 0.54 & 0.56 & 18954 & 0.45 & 0.30 & 17992 & 0.57 & 0.40 & 27905 & 0.71 & 0.47 \\
\hline December & 13744 & 0.63 & 0.63 & 16965 & 0.46 & 0.46 & 14838 & 0.58 & 0.57 & 20573 & 0.48 & 0.26 \\
\hline
\end{tabular}

Finally in Table 3 the correlations between the data from MOZAIC database and model simulations are tabulated for 4 pressure bins and 8 months. These results allow analysing the impact of the assimilation on the correlation coefficients for the simulations with and without assimilation. The results show that near the surface the impact of assimilation on the correlation coefficients is negligible. For the remaining pressure bins, the correlation coefficients increase for a great majority of the months indicating that assimilation helps in reproducing also the spatial and temporal trends seen in observations, such as the presence of $\mathrm{CO}$ anomalies. This is confirmed by reproducing Fig. 8 only for measurements that are higher than the mean plus standard deviation (figure not shown). With assimilation, the model is closer to the observations with high $\mathrm{CO}$ than the control run indicating that the assimilation of the high $\mathrm{CO}$ episodes had a positive impact on model simulations.

\subsection{POLARCAT data}

The results described in the previous section are valid for MOZAIC CO data that were measured by commercial planes in the vicinity of a small number of airports situated, for a great majority, over Western Europe and North America. To extend the comparison to other regions, we used data acquired during a recent aircraft campaign named POLARCAT. POLARCAT is an international program involving 18 countries within IPY (International Polar Year). Several aircraft were deployed in the Arctic during two intensive periods during spring and summer 2008 (Pommier et al., 2010; Paris et al., 2009; Jacob et al., 2010; Adam de Villiers et al., 2010; Roiger et al., 2011; Brock et al., 2011). An effort was made during POLARCAT to sample polluted plumes with air masses with different origins (mainly boreal forest fire plumes and anthropogenic pollution) and therefore the measurements are often not representative of climatological conditions. Since the POLARCAT campaigns focused on sources, transport pathways and climate impacts of Arc- tic pollution, the flights covered the mid and high latitudes over the Northern Hemisphere. In this article we use the CO measurements acquired during the summer campaign (July 2008), which overlaps with our simulation. The measurements provide transects at different altitudes but they also provide vertical profiles corresponding to descends and ascends of the aircraft not only near the airports but also during the flight.

Five different aircraft were involved in the summer campaigns: American DC-8 and P-3B aircraft flew mostly over the Canadian Arctic as well as the North Pole, the French and German planes, ATR-42 and Falcon-20 respectively flew over and in the vicinity of Greenland and the Russian Antonov-30 aircraft covered a relatively large area over eastern Siberia. The flight paths are shown in Fig. 10. The precision ( 1 to $5 \mathrm{ppbv}$ ) and accuracy (1 to $5 \%$ ) of the various instruments used for $\mathrm{CO}$ measurements, as well as the measurement techniques applied, have been summarised in Pommier et al. (2010). Pommier et al. (2010) contains also a comparison of POLARCAT CO measurements with the IASI retrievals when collocation is possible.

We first present a comparison of $\mathrm{CO}$ time series obtained during two DC-8 flights that traversed pollution plumes. The first analysed flight took place on 9 July 2008 over Greenland and Canadian Arctic sampling a high altitude plume with Siberian origins. This plume which contains contributions from biomass burning and anthropogenic pollution was observed by IASI as shown in Fig. 6 and as described in Pommier et al. (2010) and Sodemann et al. (2011). The analysis of the bottom left panel of Fig. 11 shows a significant improvement of the $\mathrm{CO}$ level when assimilation is used. The model with assimilation captures relatively well the presence of highly polluted air masses in the upper troposphere during the second half of the flight (bottom left panel of Fig. 11). The model values reach $200 \mathrm{ppbv}$ in agreement with observations. The control run with the monthly averaged GFEDv2 emissions is unable to reproduce these high $\mathrm{CO}$ signatures 

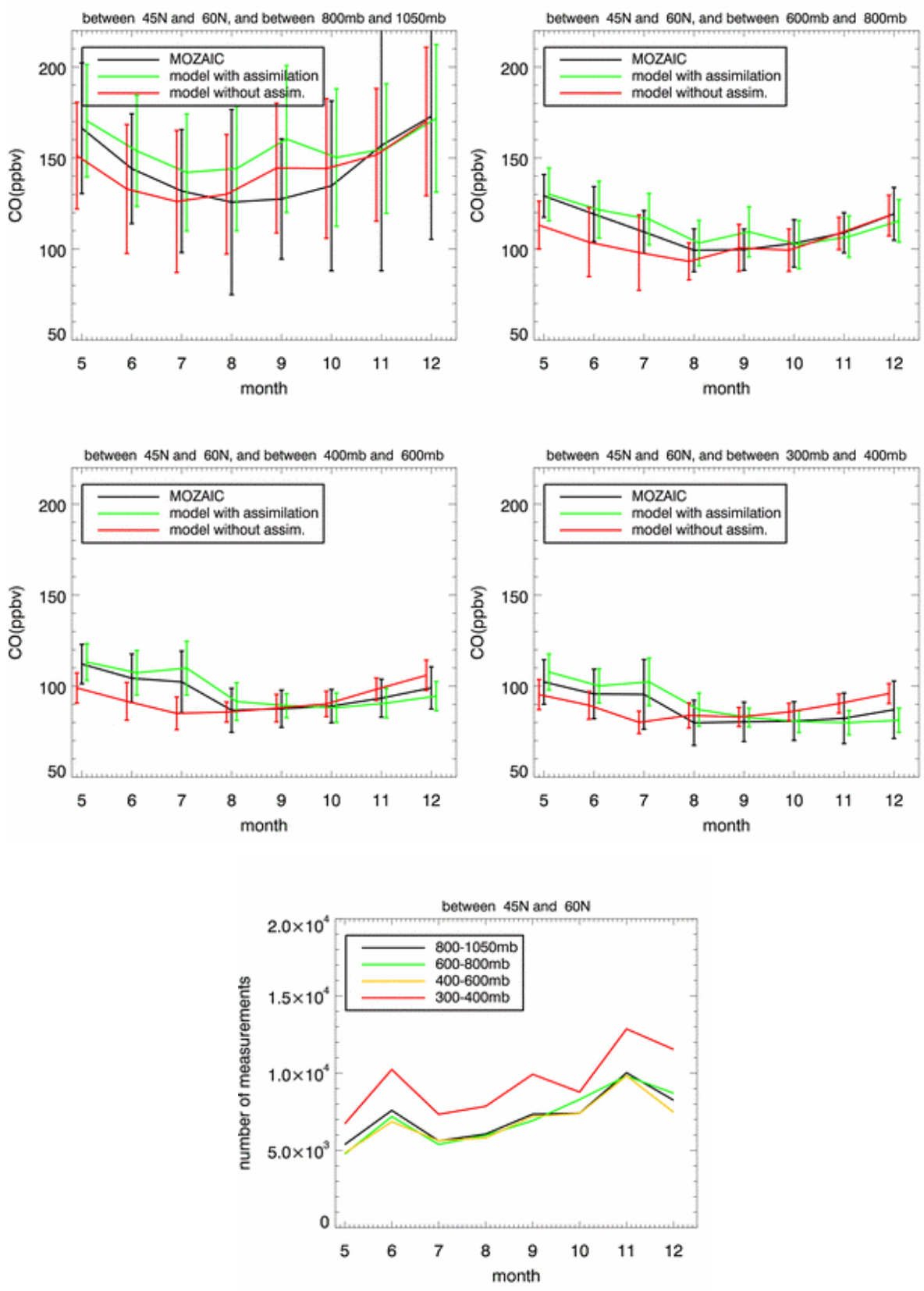

Fig. 9. Monthly averaged CO data for: MOZAIC (black curve), LMDz-INCA with assimilation of IASI CO products (green curve) and LMDz-INCA control run (red curve). The plotted data represent the means and standard deviations (error bars) for one latitude band (45$60^{\circ} \mathrm{N}$ ), for data in four pressure bins: below $800 \mathrm{mb}$ (upper left), between 800 and $600 \mathrm{mb}$ (upper right), between 600 and $400 \mathrm{mb}$ (centre left) and between 400 and $300 \mathrm{mb}$ (centre right) and from May to December 2008. The data in the lowest panel shows the number of measurements in each pressure bin as a function of month.

from biomass burning at high latitudes. One day earlier (not shown), on 8 July, the DC- 8 aircraft intercepted the outer edge of the same plume over the Canadian Arctic at about $80^{\circ} \mathrm{N}$. Again, the model with assimilation reproduces well the highly elevated values of around $150 \mathrm{ppbv}$ present in the upper troposphere at the time of the flight while the control run predicts mixing ratios below 100 ppbv. The second analysed flight took place four days earlier, on 5 July 2008. It sampled forest fires plumes over the Saskatchewan region (Canada). For this flight, the model with assimilation reproduces relatively well (and better than the control run) the elevated background values but is unable to reproduce the high CO mixing ratios (bottom right panel of Fig. 11). These peaks are likely due to relatively fresh emissions that had 


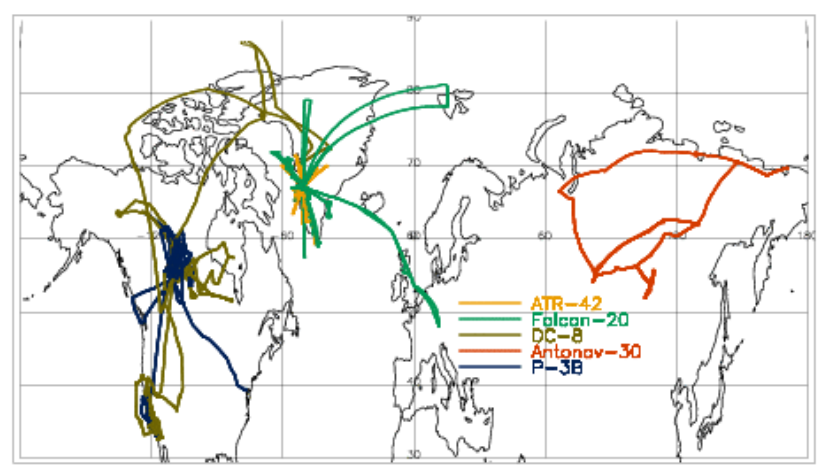

Fig. 10. Flight paths of the five aircraft during the summer campaign (June and July 2008) of POLARCAT.

less time to be diffused and also that were sampled by fewer IASI assimilation windows than the plumes present at high altitudes over Greenland on 8 and 9 July.

Figure 12 compares model results with all available POLARCAT CO measurements made by the five aircraft used during the summer campaign during the months of June and July. The panels in the left column show the mean CO profiles for observations and model with and without assimilation, while graphs in the centre column show the mean absolute difference between the observations and the two versions of the model. Both columns contain as well information on the median values, 25 and 75 percentiles. All data were averaged in $25 \mathrm{hPa}$ bins. In most cases, the assimilation of IASI observations improves the agreement between in situ $\mathrm{CO}$ values and model results. For the control run the model profiles are generally fairly constant in the vertical and are characterised by the mean background concentrations between 80 and $100 \mathrm{ppbv}$. With assimilation of the $\mathrm{CO}$ plumes observed by IASI, the model compares well with the relatively high measured values of $\mathrm{CO}$ in the middle troposphere that are due to the choice of sampling by the aircraft of polluted air masses. The position and intensity of these plumes are better simulated than with only climatological emissions present in the control run. For the ATR-42 and especially Falcon 20 (flights over Greenland) the increase of $\mathrm{CO}$ in the upper part of the troposphere is due to intense sampling by these aircraft of plumes resulting from long range transport from lower latitudes. This increase is particularly well simulated by the model when assimilation is used. For the flights of DC-8 and $\mathrm{P}-3 \mathrm{~B}$ that covered also regions much closer to the emission regions (e.g. North American forest fires), assimilation leads to a considerable improvement in the upper part of the troposphere but is unable to simulate the high mean values present near the surface. As mentioned previously, the IASI data are only weakly sensitive to these near surface plumes. The median values, which are comparable to the background values, are however well simulated by the model with assimilation for P-3B data and generally also for the DC-8 flights. For the Antonov-30 flights in Siberia, the aircraft sampled mostly background air and only a limited number of fairly weak $\mathrm{CO}$ plumes was observed near the surface. The vertical shapes of the two simulated CO profiles (assimilated and control) are similar for the Siberian data with the assimilated data being consistently higher. In the middle troposphere this increase brings the assimilated data closer to observations indicating that on average, assimilating IASI CO data helps in reproducing the correct background $\mathrm{CO}$ values in this part of the atmosphere. In the lower troposphere the control run was generally in good agreement with in situ data, and the increase observed for the assimilation run results generally in values that are too high.

Another characteristic that is improved with assimilation is the spread of the simulated $\mathrm{CO}$ mixing ratios in the middle and upper troposphere. The spread, indicated by the 25 and 75 percentiles in Fig. 12, is generally too low in both versions of the model, however the simulation with assimilation is considerably closer to observations. The centre panels in Fig. 12 indicate that the mean absolute difference between the model and observations decreases to generally between 10 and $20 \mathrm{ppbv}$ in the middle troposphere from about 30 to $60 \mathrm{ppbv}$ for the control run (with the exception of the Antonov-30 data for which the mean absolute difference with control run is generally better than $20 \mathrm{ppbv}$ ).

\subsection{Discussion of the validation results}

As shown in the above two sections, the version of the model with assimilation leads to a considerable improvement of the model results as compared with in situ measurements from the POLARCAT and MOZAIC campaigns. Assimilation helps both by improving the background values as well as the elevated concentrations measured in the pollution plumes. The consistency of these improvements for both MOZAIC and POLARCAT data contributes to the validation of the original IASI product.

For both datasets, and due to the long lifetime of $\mathrm{CO}$, assimilation acts primarily to correct errors resulting from the differences between the climatological surface emissions used in the simulations and the true emissions that took place during the analysed period. This difference can be particularly strong for emissions from forest fires, as the plumes sampled during POLARCAT, which are by nature highly episodic. In the case of boreal forest fires, elevated levels of $\mathrm{CO}$ can be injected directly into the middle troposphere where IASI is the most sensitive. The cross pole transport event represented in Fig. 6 and sampled by the DC- 8 flights on the 8 and 9 July (Fig. 11) is a good demonstration of the positive impact of assimilation on CO levels in biomass fire plumes. The cross-polar transport patterns seem to be simulated well by the model, however, in the version with climatological sources and no assimilation, too low $\mathrm{CO}$ concentrations in transported plumes are explained by too low background in the region where the plume has originated. Assimilating IASI CO helps to increase the concentrations 

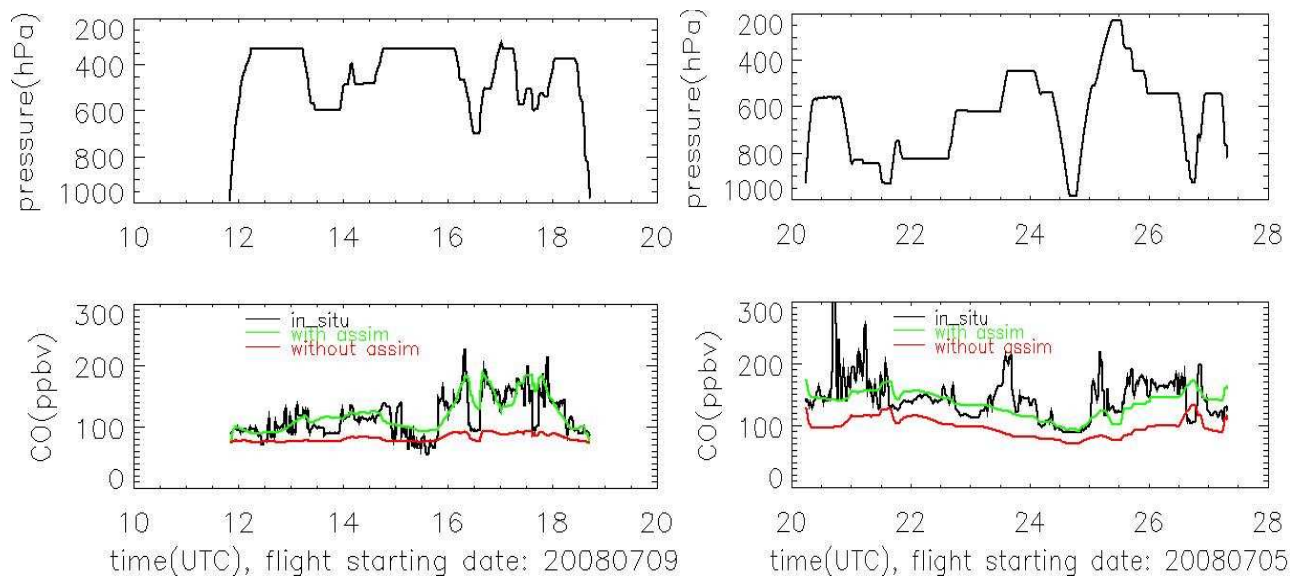

Fig. 11. Comparison of model and observed in situ CO values for two flights of DC8: left figures: 9 July over the Arctic and right figures: 5 July over Canada. The top panels show the flight pressure, lower panels show CO mixing ratio from in situ measurements (black) and the simulation with assimilation (green) and without assimilation (red).

over Siberia and when this air is transported towards the pole (no assimilation is performed north of $75^{\circ} \mathrm{N}$ ), $\mathrm{CO}$ is in better agreement with IASI and also in situ observations. Assimilation seems to modify the impact of sources also in other regions, such as south-east Asia, leading to a considerable increase of the total CO column over the North Pacific as shown in Fig. 5. Assimilation can also correct for other model related deficiencies such as, for example, horizontal transport and especially vertical transport out of the boundary layer.

As the IASI CO products are mostly sensitive to the $\mathrm{CO}$ column in the middle troposphere, most of the improvement is present in this part of the atmosphere. Relatively little improvement is observed near the surface. An example can be seen for the POLARCAT data over Siberia sampled by the Antonov-30 aircraft. Over Siberia the CO emissions from fires and other diffused sources have lower emission heights than for other boreal forest fires. The few near-surface COrich episodes sampled by the aircraft were not reproduced in the model with assimilation. Assimilation increases however, in agreement with aircraft observations, the mixing ratios in the middle troposphere. Similarly, when model results are compared with in situ surface data (not shown), little or no positive impact of assimilation is seen. Clear improvement is observed only in remote polar regions of the southern hemisphere. In those regions that are far from strong emission, the vertical profile of $\mathrm{CO}$ varies little and by removing the bias in the mid-troposphere, the information is also transported with time to the lower levels due to vertical mixing. For other remote locations, the version with assimilation, while generally improving the background surface values, shows episodic CO peaks that are not present in observations. The presence of these peaks corresponds to the $\mathrm{CO}$ plumes in the higher levels of the troposphere, and indicates a possible too strong vertical mixing in the model.

\section{Summary}

In this paper we present the work carried out in order to contribute to the validation of the $\mathrm{CO}$ columns retrieved from the IASI measurements. Eight months of IASI CO columns from May until December 2008 were assimilated into the LMDZINCA global chemistry transport model, and the assimilated data were compared with in-situ measurements from the MOZAIC program and from the POLARCAT summer campaign. One of the advantages of using the assimilated values in the comparison is that assimilation provides global and continuous maps of the CO column that are not limited to the overpass of the satellite. In addition, the assimilated product contains information on the vertical distribution of $\mathrm{CO}$. Both of these characteristics simplify considerably the comparison with the in situ data that are rarely collocated with the IASI measurements, and that rarely have enough vertical extent for a comparison to column-like satellite observations. It was found that in the mid-troposphere assimilation leads to a consistent reduction of the differences between the model values and in situ aircraft data measured during MOZAIC and POLARCAT flights. This improvement is observed despite the relatively limited vertical resolution of the IASI CO product that smoothes out any features with high vertical resolution. The general improvement of the model with assimilation, as compared with the control simulation, when evaluated against in situ aircraft data in the mid troposphere, is an important contribution to the validation of the IASI CO product.

Near the surface the impact of assimilation is much less beneficial. The lowest troposphere contributes less to the IASI CO product, and the simulated values are not well constrained by the assimilation. Model deficiencies leading mainly to incorrect $\mathrm{CO}$ mixing ratios in the lowest part of the troposphere, such as incorrect sources, too fast vertical 

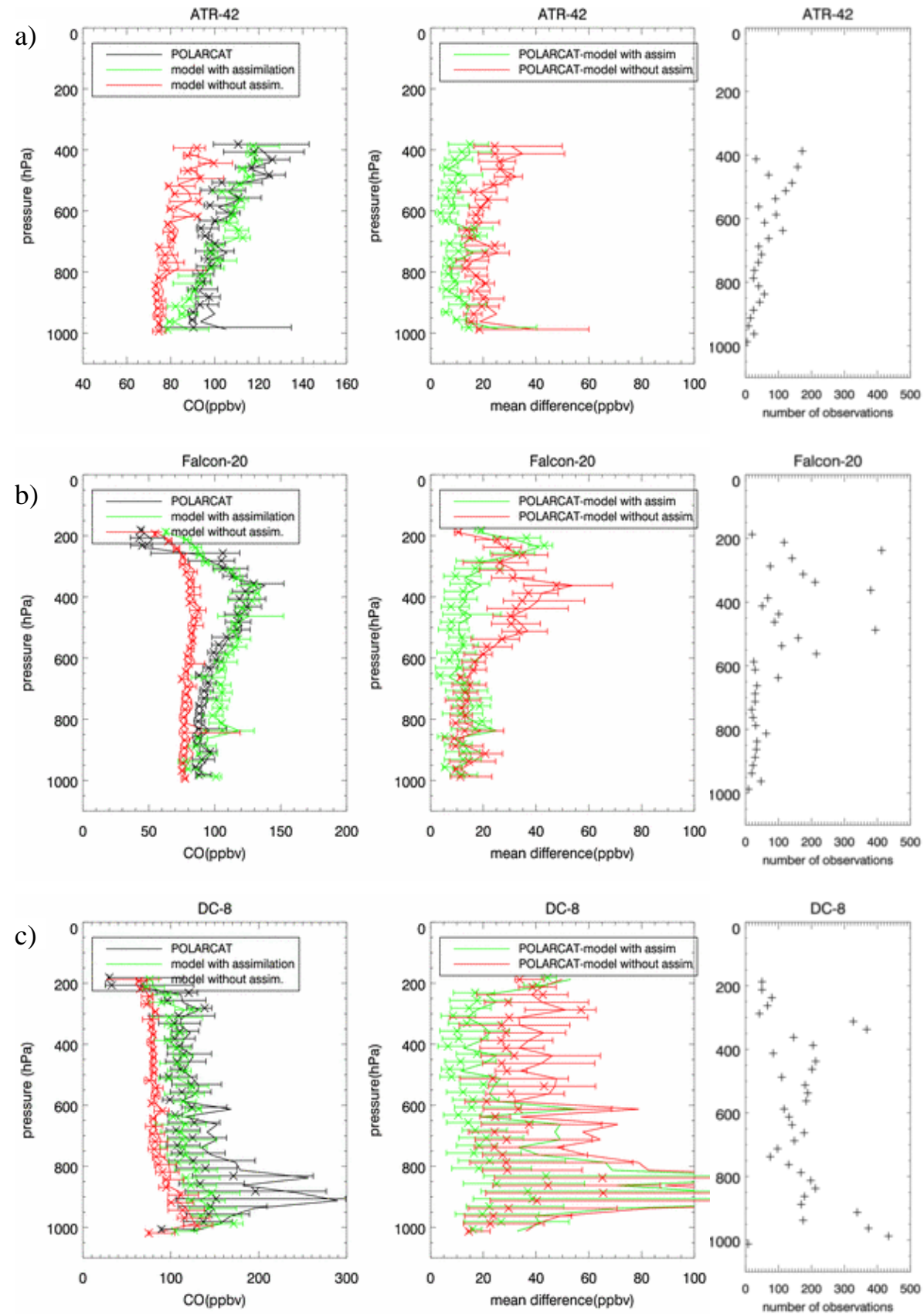

Fig. 12. Left column: solid lines show mean CO profiles for simulation with assimilation (green), control run (red) and in situ measurements (black). Centre column: mean absolute difference between CO data from POLARCAT observations and model with assimilation (green), and observations and control model run (red). The horizontal bars in the left and centre column panels indicate the 25 and 75 percentiles, and the symbol $x$ indicates the median. The right column indicates the number of POLARCAT measurements for each aircraft. Data are plotted for July 2008 for the ATR-42 (a), the Falcon-20 (b), the DC-8 (c), the P-3B (d) and the Antonov-30 (e). Continued on next page.

mixing with the free troposphere or incorrect boundary layer height, will not be corrected for. Incorrect mixing and weak sensitivity of the IASI product to the near surface values can lead to errors in any studies leading to the inversion of the $\mathrm{CO}$ surface source. Too high rate of exchange between the boundary layer and free troposphere would lead to an under- estimation of the $\mathrm{CO}$ fluxes derived from the inversion of the IASI data.

In addition to the validation of the IASI CO product, the article is a part of the POLARCAT effort as it simulates the transport of pollution plumes sampled by aircraft. We show that with assimilation the model better simulates the elevated 

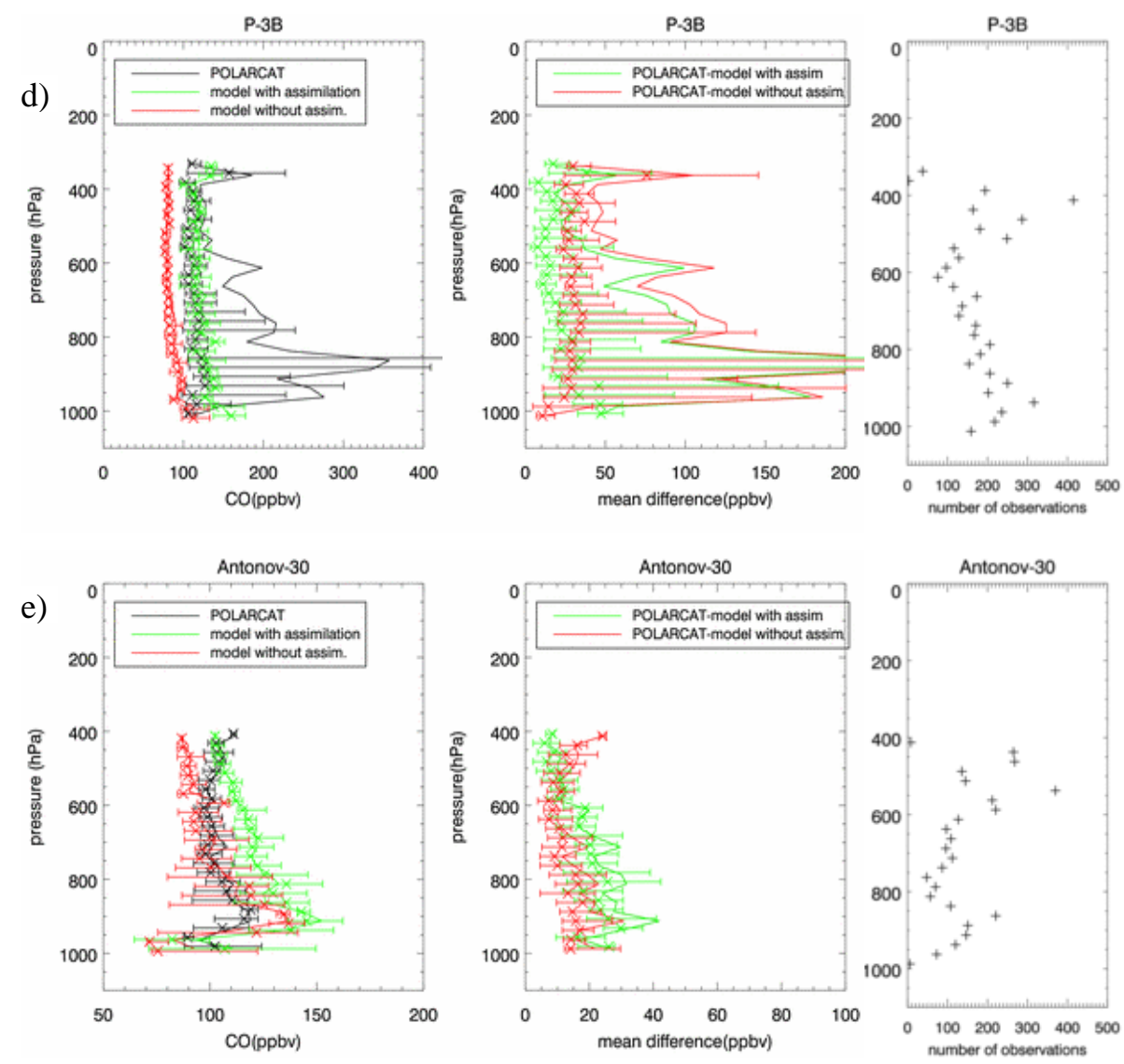

Fig. 12. Continued from previous page. Left column: solid lines show mean CO profiles for simulation with assimilation (green), control run (red) and in situ measurements (black). Centre column: mean absolute difference between CO data from POLARCAT observations and model with assimilation (green), and observations and control model run (red). The horizontal bars in the left and centre column panels indicate the 25 and 75 percentiles, and the symbol $x$ indicates the median. The right column indicates the number of POLARCAT measurements for each aircraft. Data are plotted for July 2008 for the P-3B (d) and the Antonov-30 (e).

concentrations inside the plumes reaching the Arctic. This is particularly true for elevated plumes representing transport from remote sources. As shown for example for the cross pole transport event that took place on 8-12 July, the control run was not able to simulate the concentrations measured by aircraft around Greenland because the concentrations in the source region over Asia were too small. Assimilation of IASI CO data led to a considerable increase in CO over Asia that corrected for the deficiency of the climatological emissions and led to a higher, more realistic transport of pollution into the Arctic region (no assimilation was performed above $\left.75^{\circ} \mathrm{N}\right)$

In a parallel experiment related to the POLARCAT campaign, the version of the model with assimilation has been run in a forecast mode using forecast winds and initial conditions updated with the most recent observations. This version can be a very useful tool for planning the aircraft flight paths during the field missions. The model can act as a tool that transports the plumes seen in the recent IASI CO data forward in time thus allowing an identification of regions were the pollution concentration is likely to be elevated. The posterior simulations performed for the POLARCAT flights show that indeed the assimilated IASI CO plumes present in the model initial conditions are transported in time in good agreement with the IASI observations obtained over the following day.

Assimilation of IASI total CO columns used in this work is now also performed with 4DVAR methods in the framework of the Monitoring Atmospheric Composition and Climate (MACC-II) project, the current pre-operational atmospheric service of the European GMES programme led by ECMWF (Hollingsworth et al., 2008). The near real time assimilation of IASI data (less than $3 \mathrm{~h}$ after the observation) allows providing $\mathrm{CO}$ forecast for the next three days (for maps see http://www.gmes-atmosphere.eu/d/services/ gac/nrt/nrt_fields). The work presented in this paper has served as the first experience with the assimilation of the IASI total CO columns. 
Acknowledgements. IASI was developed and built under the responsibility of CNES and flies onboard the MetOp satellite as part of the Eumetsat Polar system. The authors acknowledge the Ether French atmospheric database (http://ether.ipsl.jussieu.fr) for distributing the IASI L1C data. NOVELTIS and the French coauthors are grateful to CNES for his continuous scientific and financial support. POLARCAT-France was funded by French ANR, CNES, CNRS-INSU (LEFE-CHAT), IPEV and also EUFAR.

POLARCAT-GRACE was funded by DLR. The YAK-AEROSIB campaigns were funded by the CNRS-DRI (France), the French Ministry of Foreign Affairs, CEA (France), POLARCAT France/Norway, RAS (Russia) and RFBR (Russia), and operated in collaboration with IAO-SB-RAS, Tomsk, Russia.

The authors acknowledge the strong support of the European Commission, Airbus, and the Airlines (Lufthansa, Austrian, Air France) who carry free of charge the MOZAIC equipment and perform the maintenance since 1994. MOZAIC is presently funded by INSU-CNRS (France), Meteo-France, and Forschungszentrum (FZJ, Julich, Germany). The MOZAIC data based is supported by ETHER (CNES and INSU-CNRS).

M. Pommier was supported by a fellowship grant from NOVELTIS, Centre National d'Etudes Spatiales (CNES, France) and from Natural Sciences and Engineering Research Council of Canada (NSERC, Canada).

The research in Belgium was funded by the "Actions de Recherche Concertées" (Communauté Française), the Fonds National de la Recherche Scientifique (FRS-FNRS F.4511.08), the Belgian State Federal Office for Scientific, Technical and Cultural Affairs and the European Space Agency (ESA-Prodex C90-327).

All the simulations were performed at the computing center CCRT/GENCI.

We thank Maya George (LATMOS) for her help with preparing IASI CO data used in this work.

Funding support from the French projects Climate Impact of Short-lived Pollutants and Methane in the Arctic (CLIMSLIP) ANR Blanc SIMI 5-6021 01 and CLIMSLIP-LEFE (CNRS-INSU) are also acknowledged.

Edited by: A. Stohl

\section{References}

Adam de Villiers, A. R., Ancellet, G., Pelon, J., Quennehen, B., Schwarzenboeck, A., Gayet, J. F., and Law, K. S.: Airborne measurements of aerosol optical properties related to early 10 spring transport of mid-latitude sources into the Arctic, Atmos. Chem. Phys., 10, 5011-5030, doi:10.5194/acp-10-5011-2010, 2010.

Brock, C. A., Cozic, J., Bahreini, R., Froyd, K. D., Middlebrook, A. M., McComiskey, A., rioude, J., Cooper, O. R., Stohl, A., Aikin, K. C., de Gouw, J. A., Fahey, D. W., Ferrare, R. A., Gao, R.-S., Gore, W., Holloway, J. S., H“ubler, G., Jefferson, A., Lack, D. A., Lance, S., Moore, R.H., Murphy, D. M., Nenes, A., Novelli, P. C., Nowak, J. B., Ogren, J. A., Peischl, J., Pierce, R.B., Pilewskie, P., Quinn, P. K., Ryerson, T. B., Schmidt, K. S., Schwarz, J. P., Sodemann, H., Spackman, J. R., Stark, H., Thomson, D. S., Thornberry, T., Veres, P., Watts, L. A., Warneke, C., and Wollny, A. G.:
Characteristics, sources, and transport of aerosols measured in spring 2008 during the aerosol, radiation, and cloud processes affecting Arctic Climate (ARCPAC) Project, Atmos. Chem. Phys., 11, 2423-2453, doi:10.5194/acp-11-2423-2011, 2011.

Cammas, J.-P., Brioude, J., Chaboureau, J.-P., Duron, J., Mari, C., Mascart, P., Nédélec, P., Smit, H., Pätz, H.-W., Volz-Thomas, A., Stohl, A., and Fromm, M.: Injection in the lower stratosphere of biomass fire emissions followed by long-range transport: a MOZAIC case study, Atmos. Chem. Phys., 9, 5829-5846, doi:10.5194/acp-9-5829-2009, 2009.

Clarisse, L., R'Honi, Y., Coheur, P.-F., Hurtmans, D., and Clerbaux, C.: Thermal infrared nadir observations of 24 atmospheric gases, Geophys. Res. Lett., 38, L10802, doi:10.1029/2011GL047271, 2011.

Clerbaux, C., Hadji-Lazaro, J., Hauglustaine, D., Mégie, G., Khattatov, B., and Lamarque, J.-F.: Assimilation of carbon monoxide measured from satellite in a three dimensional chemistry transport model, J. Geophys. Res., 106, 15385-15394, 2001.

Clerbaux, C., George, M., Turquety, S., Walker, K. A., Barret, B., Bernath, P., Boone, C., Borsdorff, T., Cammas, J. P., Catoire, V., Coffey, M., Coheur, P.-F., Deeter, M., De Mazière, M., Drummond, J., Duchatelet, P., Dupuy, E., de Zafra, R., Eddounia, F., Edwards, D. P., Emmons, L., Funke, B., Gille, J., Griffith, D. W. T., Hannigan, J., Hase, F., Höpfner, M., Jones, N., Kagawa, A., Kasai, Y., Kramer, I., Le Flochmoën, E., Livesey, N. J., López-Puertas, M., Luo, M., Mahieu, E., Murtagh, D., Nédélec, P., Pazmino, A., Pumphrey, H., Ricaud, P., Rinsland, C. P., Robert, C., Schneider, M., Senten, C., Stiller, G., Strandberg, A., Strong, K., Sussmann, R., Thouret, V., Urban, J., and Wiacek, A.: CO measurements from the ACE-FTS satellite instrument: data analysis and validation using ground-based, airborne and spaceborne observations, Atmos. Chem. Phys., 8, 2569-2594, doi:10.5194/acp-8-2569-2008, 2008.

Clerbaux, C., Boynard, A., Clarisse, L., George, M., Hadji-Lazaro, J., Herbin, H., Hurtmans, D., Pommier, M., Razavi, A., Turquety, S., Wespes, C., and Coheur, P.-F.: Monitoring of atmospheric composition using the thermal infrared IASI/METOP sounder, Atmos. Chem. Phys., 9, 6041-6054, doi:10.5194/acp-9-60412009, 2009.

Deeter, M. N., Edwards, D. P., Gille, J. C., Emmons, L. K., Francis, G., Ho, S.-P., Mao, D., Masters, D., Worden, H., Drummond, J. R., and Novelli, P. C.: The MOPITT version 4 CO product: Algorithm enhancements, validation, and long-term stability, J. Geophys. Res., 115, D07306, doi:10.1029/2009JD013005, 2010.

Duncan, B. N., Logan, J. A., Bey, I., Megretskaia, I. A., Yantosca, R. M., Novelli, P. C., Jones, N. B., and Rinsland, C. P.: Global budget of CO, 1988 - 1997: Source estimates and validation with a global model, J. Geophys. Res., 112, D22301, doi:10.1029/2007JD008459, 2007.

Elbern, H. and Schmidt, H.: A four-dimensional variational chemistry data assimilation scheme for Eulerian chemistry transport modeling, J. Geophys. Res., 104, 18583-18598, doi:10.1029/1999JD900280, 1999.

Folberth, G. A., Hauglustaine, D. A., Lathière, J., and Brocheton, F.: Impact of Biogenic Hydrocarbons on Tropospheric Chemistry: Results from a Global Chemistry-Climate Model, Atmos. Chem. Phys., 6, 2273-2319, doi:10.5194/acp-6-2273-2006, 2006.

Fortems-Cheiney, A., Chevallier, F., Pison, I., Bousquet, P., Carouge, C., Clerbaux, C., Coheur, P.-F., George, M., Hurtmans, 
D., and Szopa, S.: On the capability of IASI measurements to inform about CO surface emissions, Atmos. Chem. Phys., 9, 87358743, doi:10.5194/acp-9-8735-2009, 2009.

George, M., Clerbaux, C., Hurtmans, D., Turquety, S., Coheur, P.F., Pommier, M., Hadji-Lazaro, J., Edwards, D.-P., Worden, H., Luo, M., Rinsland, C., and McMillan, W.: Carbon monoxide distributions from the IASI/METOP mission: evalutation with other space-borne sensors, Atmos. Chem. Phys., 9, 8317-8330, doi:10.5194/acp-9-8317-2009, 2009.

Gloudemans, A. M. S., Krol, M. C., Meirink, J. F., de Laat, A. T. J., van der Werf, G. R., Schrijver, H., van den Broek, M. M. P., and Aben, I.: Evidence for long-range transport of carbon monoxide in the Southern Hemisphere from SCIAMACHY observations, Geophys. Res. Lett., 33, L16807, doi:10.1029/2006GL026804, 2006.

Hauglustaine, D. A., Hourdin, F., Jourdain, L., Filiberti, M.A., Walters, S., Lamarque, J.-F., and Holland, E. A.: Interactive chemistry in the Laboratoire de Météorologie Dynamique general circulation model: Description and background tropospheric chemistry evaluation, J. Geophys. Res., 109, D04314, doi:10.1029/2003JD003957, 2004.

Hollingsworth, A., Engelen, R. J., Textor, C., Benedetti, A., Boucher, O., Chevallier, F., Dethof, A., Elbern, H., Eskes, H., Flemming, J., Granier, C., Kaiser, J. W., Morcrette, J.-J., Rayner, P., Peuch, V.-H., Rouil, L., Schultz, M. G., Simmons, A. J., and the GEMS Consortium: Toward a monitoring and forecasting system for atmospheric composition: The Gems Project, B. Am. Meteor. Soc., 89, 1147-1164, doi:10.1175/2008BAMS2355.1, 2008.

Hourdin, F., Musat, I., Bony, S., Braconnot, P., Codron, F., Dufresne, J.-L., Fairhead, L., Filiberti, M.-A., Friedlingstein, P., Grandpeix, J.-Y., Krinner, G., LeVan, P., Li, Z. X., and Lott, F.: The LMDZ4 general circulation model: climate performance and sensitivity to parametrized physics with emphasis on tropical convection, Clim. Dynam., 27, 787-813, 2006.

Hurtmans, D., Coheur, P.-F., Wespes, C., Clarisse, L., Scharf, O., Clerbaux, C., Hadji-Lazaro, J., George, M., and Turquety, S.: FORLI radiative transfer and retrieval code for IASI, J. Quant. Spectrosc. Rad. T., doi:10.1016/j.jqsrt.2012.02.036, in press, 2012.

Jacob, D. J., Crawford, J. H., Maring, H., Clarke, A. D., Dibb, J. E., Emmons, L. K., Ferrare, R. A., Hostetler, C. A., Russell, P. B., Singh, H. B., Thompson, A. M., Shaw, G. E., McCauley, E., Pederson, J. R., and Fisher, J. A.: The Arctic Research of the Composition of the Troposphere from Aircraft and Satellites (ARCTAS) mission: design, execution, and first results, Atmos. Chem. Phys., 10, 5191-5212, doi:10.5194/acp-10-5191-2010, 2010.

Khattatov, B. V., Lamarque, J.-F., Lyjak, L. V., Menard, R., Levelt, P. F., Tie, X. X., Brasseur, G. P., and Gille, J. C.: Assimilation of satellite observations of long-lived chemical species in global chemistry-transport models, J. Geophys. Res., 105, 29135-29144, doi:10.1029/2000JD900466, 2000.

Klonecki, A., Hess, P., Emmons, L., Smith, L., Orlando, J., and Blake, D.: Seasonal changes in the transport of pollutants into the Arctic troposphere-model study, J. Geophys. Res., 108, 8367, doi:10.1029/2002JD002199, 2003.

Lamarque, J.-F., Khattatov, B. V., Gille, J. C., and Brasseur, G. P.: Assimilation of Measurement of Air Pollution from Space (MAPS) CO in a global three-dimensional model, J. Geophys.
Res., 104, 26209-26218, 1999.

Lamarque, J.-F., Khattatov, B., Yudin, V., Edwards D. P., Gille, J. C., Emmons, L. K., Deeter, M. N., Warner, J., Ziskin, D. C., Francis, G. L., Ho, S., Mao, D., Chen, J., and Drummond, J. R., Application of a bias estimator for the improved assimilation of Measurements of Pollution in the Troposphere (MOPITT) carbon monoxide retrievals, J. Geophys. Res., 109, D16304, doi:10.1029/2003JD004466, 2004.

Lamarque, J.-F., Bond, T. C., Eyring, V., Granier, C., Heil, A., Klimont, Z., Lee, D., Liousse, C., Mieville, A., Owen, B., Schultz, M. G., Shindell, D., Smith, S. J., Stehfest, E., Van Aardenne, J., Cooper, O. R., Kainuma, M., Mahowald, N., McConnell, J. R., Naik, V., Riahi, K., and van Vuuren, D. P.: Historical (1850-2000) gridded anthropogenic and biomass burning emissions of reactive gases and aerosols: methodology and application, Atmos. Chem. Phys., 10, 7017-7039, doi:10.5194/acp10-7017-2010, 2010.

Lathière, J., Hauglustaine, D. A., Friend, A. D., De NobletDucoudré, N., Viovy, N., and Folberth, G. A.: Impact of climate variability and land use changes on global biogenic volatile organic compound emissions, Atmos. Chem. Phys., 6, 2129-2146, doi:10.5194/acp-6-2129-2006, 2006.

Logan, J., Prather, M. J., Wofsy, S. C., and McElroy, M. B.: Tropospheric chemistry: A global perspective, J. Geophys. Res., 86, 7210-7254, 1981.

Luo, M., Rinsland, C. P., Rodgers, C. D., Logan, J. A., Worden, H., Kulawik, S., Eldering, A., Goldman, A., Shephard, M. W., Gunson, M., and Lampel, M.: Comparison of carbon monoxide measurements by TES and MOPITT: Influence of a priori data and instrument characteristics on nadir atmospheric species retrievals, J. Geophys. Res., 112, D09303, doi:10.1029/2006JD007663, 2007.

McMillan, W. W., Barnet, C., Strow, L., Chahine, M. T., McCourt, M. L., Warner, J. X., Novelli, P. C., Korontzi, S., Maddy, E. S., and Datta, S.: Daily global maps of carbon monoxide from NASA's Atmospheric Infrared Sounder, Geophys. Res. Lett., 32, L11801, doi:10.1029/2004GL021821, 2005.

McMillan, W. W., Warner, J. X., McCourt Comer, M., Maddy, E., Chu, A., Sparling, L., Eloranta, E., Hoff, R., Sachse, G., Barnet, C., Razenkov, I., and Wolf, W.: AIRS views transport from 1210 to 22 July 2004 Alaskan/Canadian fires: Correlation of AIRS CO and MODIS AOD with forward trajectories and comparison of AIRS CO retrievals with DC-8 in situ measurements during INTEX-A/ICARTT, J. Geophys. Res., 113, D20301, doi:10.1029/2007JD009711, 2008.

Nédélec, P., Cammas, J.-P., Thouret, V., Athier, G., Cousin, J.-M., Legrand, C., Abonnel, C., Lecoeur, F., Cayez, G., and Marizy, C.: An improved infrared carbon monoxide analyser for routine measurements aboard commercial Airbus aircraft: technical validation and first scientific results of the MOZAIC III programme, Atmos. Chem. Phys., 3, 1551-1564, doi:10.5194/acp-3-15512003, 2003.

Novelli, P. C., Masarie, K. A., Lang, P. M., Hall, B. D., Myers, R. C., and Elkins, J.W.: Reanalysis of tropospheric CO trends: Effects of the 1997-1998 wildfires, J. Geophys. Res., 108, 4464, doi:10.1029/2002JD003031, 2003.

Paris, J.-D., Stohl, A., Nédélec, P., Arshinov, M. Yu., Panchenko, M. V., Shmargunov, V. P., Law, K. S., Belan, B. D., and Ciais, P.: Wildfire smoke in the Siberian Arctic in summer: source charac- 
terization and plume evolution from airborne measurements, Atmos. Chem. Phys., 9, 9315-9327, doi:10.5194/acp-9-9315-2009, 2009.

Pommier, M., Law, K. S., Clerbaux, C., Turquety, S., Hurtmans, D., Hadji-Lazaro, J., Coheur, P.-F., Schlager, H., Ancellet, G., Paris, J.-D., Nédélec, P., Diskin, G. S., Podolske, J. R., Holloway, J. S., and Bernath, P.: IASI carbon monoxide validation over the Arctic during POLARCAT spring and summer campaigns, Atmos. Chem. Phys., 10, 10655-10678, doi:10.5194/acp-1010655-2010, 2010.

Pradier, S., Attié, J.-L., Chong, M., Escobar, J., Peuch, V.-H., Lamarque, J.-F., Khattatov, B., and Edwards, D.: Evaluation of 2001 springtime CO transport over West Africa using MOPITT $\mathrm{CO}$ measurements assimilated in a global chemistry transport model, Tellus B - Chem. Phys. Meteorol., B, 58, 163-176, 2006.

Roiger, A., Schlager, H., Schäfler, A., Huntrieser, H., Scheibe, M., Aufmhoff, H., Cooper, O. R., Sodemann, H., Stohl, A., Burkhart, J., Lazzara, M., Schiller, C., Law, K. S., and Arnold, F.: Insitu observation of Asian pollution transported into the Arctic lowermost stratosphere, Atmos. Chem. Phys., 11, 10975-10994, doi:10.5194/acp-11-10975-2011, 2011.

Shindell, D. T., Chin, M., Dentener, F., Doherty, R. M., Faluvegi, G., Fiore, A. M., Hess, P., Koch, D. M., MacKenzie, I. A., Sanderson, M. G., Schultz, M. G., Schulz, M., Stevenson, D. S., Teich, H., Textor, C., Wild, O., Bergmann, D. J., Bey, I., Bian, H., Cuvelier, C., Duncan, B. N., Folberth, G., Horowitz, L. W., Jonson, J., Kaminski, J. W., Marmer, E., Park, R., Pringle, K. J., Schroeder, S., Szopa, S., Takemura, T., Zeng, G., Keating, T. J., and Zuber, A.: A multi-model assessment of pollution transport to the Arctic, Atmos. Chem. Phys., 8, 5353-5372, doi:10.5194/acp-8-5353-2008, 2008.

Sodemann, H., Pommier, M., Arnold, S. R., Monks, S. A., Stebel, K., Burkhart, J. F., Hair, J. W., Diskin, G. S., Clerbaux, C., Coheur, P.-F., Hurtmans, D., Schlager, H., Blechschmidt, A.-M., Kristjánsson, J. E., and Stohl, A.: Episodes of cross-polar transport in the Arctic troposphere during July 2008 as seen from models, satellite, and aircraft observations, Atmos. Chem. Phys., 11, 3631-3651, doi:10.5194/acp-11-3631-2011, 2011.
Turquety, S., Hurtmans, D., Hadji-Lazaro, J., Coheur, P.-F., Clerbaux, C., Josset, D., and Tsamalis, C.: Tracking the emission and transport of pollution from wildfires using the IASI CO retrievals: analysis of the summer 2007 Greek fires, Atmos. Chem. Phys., 9, 4897-4913, doi:10.5194/acp-9-4897-2009, 2009.

Van der Werf, G. R., Randerson, J. T., Giglio, L., Collatz, G. J., Kasibhatla, P. S., and Arellano, A. F.: Interannual variability in global biomass burning emissions from 1997 to 2004, Atmos. Chem. Phys., 6, 3423-3441, doi:10.5194/acp-6-3423-2006, 2006.

Wan, Z.: New refinements and validation of the MODIS landsurface temperature/emissivity products, Remote Sens. Environ., 112, 59-74, 2008

Warneke, C., Bahreini, R., Brioude, J., Brock, C. A., de Gouw, J. A. , Fahey, D. W. , Froyd, K. D., Holloway, J. S., Middlebrook, A., Miller, L. , Montzka, S., Murphy, D. M., Peischl, J., Ryerson, T. B., Schwarz, J. P., Spackman, J. R., and Veres, P. : Biomass burning in Siberia and Kazakhstan as an important source for haze over the Alaskan Arctic in April 2008, Geophys. Res. Lett., 36, L02813, doi:10.1029/2008GL036194, 2009.

Zander, R., Mahieu, E., Demoulin, P., Duchatelet, P., Roland, R., Servais, C., De Mazière, M., Reimann, S., and Rinsland, C. P. Our changing atmosphere: Evidence based on long-term infrared solar observations at the Jungfraujoch since 1950, Sci. Total Environ., 391, 184-195, doi:10.1016/j.scitotenv.2007.10.018, 2008. 